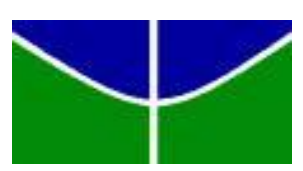

Universidade de Brasília - UnB

Faculdade de Economia, Administração, Contabilidade e Ciência da informação e Documentação - FACE Departamento de Ciência da Informação e Documentação - CID

ROBERTA DANNEMANN VARGAS

\title{
DESENVOLVIMENTO DO GOSTO PELA LEITURA NA PRIMEIRA INFÂNCIA: projetos escolares
}


ROBERTA DANNEMANN VARGAS

\section{DESENVOLVIMENTO DO GOSTO PELA LEITURA NA PRIMEIRA INFÂNCIA: projetos escolares}

Monografia apresentada ao curso de Graduação em Biblioteconomia da Universidade de Brasília como requisito parcial para obtenção do Título de Bacharel.

Orientadora: Suzana P. M. Mueller

BRASÍLIA 
"None but ourselves can free our minds. Have no fear for atomic energy, cause none of them can stop the time."

Bob Marley 


\section{RESUMO}

O foco desta pesquisa é verificar em instituições de ensino a existência de programas de incentivo à descoberta da leitura pelas crianças antes dos cinco anos e desta forma contribuir para o esforço das escolas na formação de leitores. Desenvolveu-se um estudo de caso descritivo qualitativo, em que duas instituições de ensino em Brasília foram selecionadas, uma pública e uma particular, e seus projetos de leitura se tornaram objeto do estudo. A coleta dos dados foi realizada por meio de entrevista semi estruturada, além de visitas preliminares às instituições. As respostas foram analisadas e comparadas, tendo como parâmetros dados apreendidos na literatura. Observou-se que nos universos aparentemente distintos das escolas, os projetos se assemelham assim como as atividades propostas. Entre os pontos em comum há o fato de que ambos tiveram origem no entusiasmo de uma pessoa, mas diferentemente da escola particular, onde há a possibilidade de continuidade, na escola publica, a existência do projeto parece depender de iniciativas pessoais, não institucionais.

PALAVRAS - CHAVE: Leitura na infância; Projeto de leitura em escolas - Distrito Federal; Hábito de leitura na infância: programas escolares; 


\begin{abstract}
The topic of this study is the effort developed by schools to lead young children into reading habits. Programs geared to children under the age of five, offered by two schools located in Brasilia, were investigated. Data were collected through a semi-structured interview with the responsible person in each school, which were preceded by analysis of the available written information and visits to each school. Information gathered was compared, having as parameters the literature on the subject. Results indicated that, despite the difference in means available to the schools, both projects present equally good results and have many points in common, such as owing its origins to the enthusiasm of one person. But the projects also present differences, such as the hope for continuation, which in the public school seems to depend exclusively on the enthusiasm of one teacher.
\end{abstract}

KEYWORDS: Reading habits in young children; Reading-inducing projects in Brasilia, Brazil, schools. 
SUMÁRIO

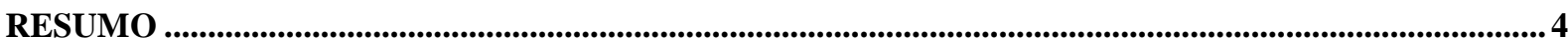

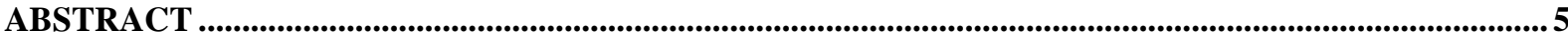

1. INTRODUÇÃO

2. A CRIANÇA E A LEITURA .......................................................................................................................

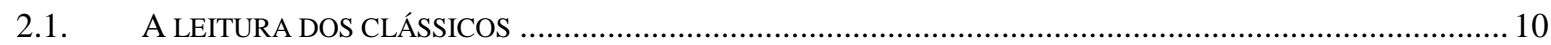

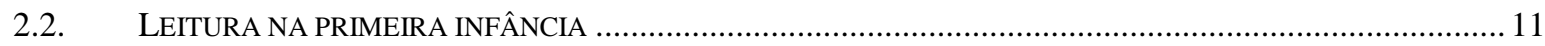

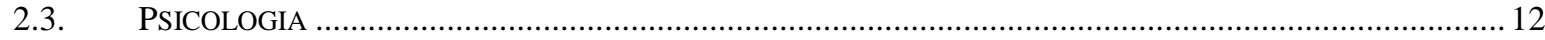

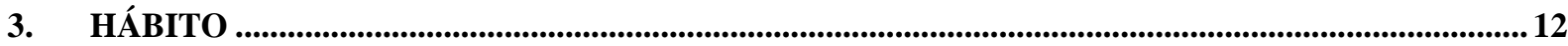

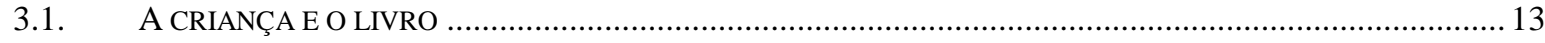

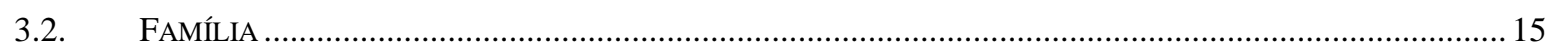

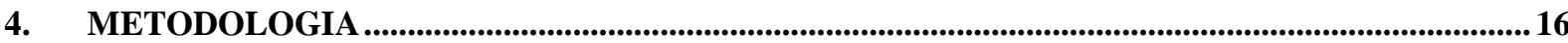

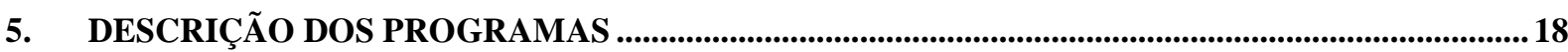

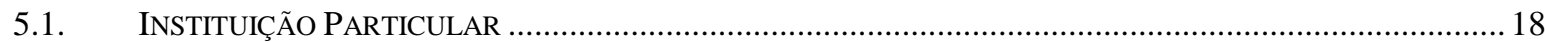

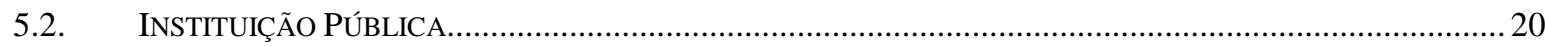

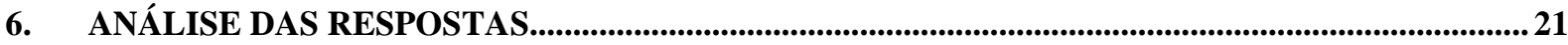

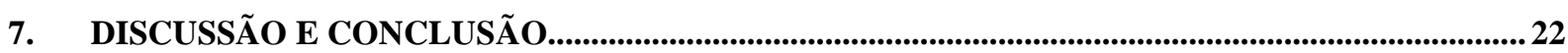

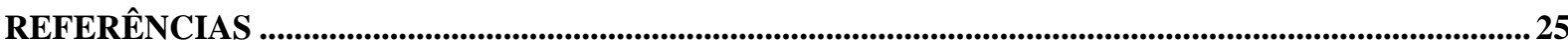

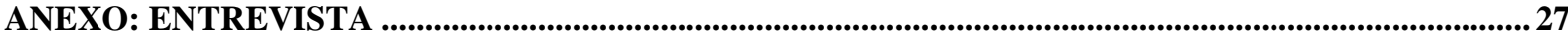

ANEXO: INSTITUIÇÃO PRIVADA - MARISTA JOÃO PAULO II .......................................................... 28

ANEXO: INSTITUIÇÃO PÚBLICA - JARDIM 304 NORTE.............................................................................34

ANEXO: JARDIM 304 NORTE - EXERCÍCIOS PROPOSTOS ..................................................................... 41 


\section{INTRODUÇÃO}

No Brasil existe uma situação preocupante em relação à leitura, principalmente durante o período pré escolar, ou seja, antes dos seis anos. Existem diversas questões que denunciam os reais motivos para a não prática da leitura entre as crianças alfabetizadas ou em fase de alfabetização no Brasil. AZEVEDO (1999, p. 1) em um dos seus diversos artigos publicados nesta área, cita e observa que estes motivos estão intimamente conectados.

A condição social dos alunos os impede de adquirir obras visto que seus valores não são acessíveis no Brasil, assim, até professores e pais não podem dar o exemplo de reais leitores para as crianças. Segundo o estudo do Instituto Pró-Livro uma "enorme fatia da população não conhece os materiais de leitura, ou conhece muito mal” (CUNHA, 2008, p. 12). O pouco investimento governamental não permite que a população tenha bibliotecas ou salas de leituras adequadas tanto para os adultos quanto para as crianças. Sem a preocupação das autoridades responsáveis, dificilmente nossas crianças serão estimuladas a conhecer o universo dos livros e desenvolver atividade crítica.

A visão da biblioteca enquanto um espaço para guardar livros velhos (antigos) devidamente organizados por uma bibliotecária e que não devem ser utilizados, ou um ambiente de punição para alunos atrasados ou retirados de sala é latente nas escolas, porém poderia ser transformada para o que a biblioteca representa para uma pequena parte da população. É possível passar para as crianças a imagem, em primeiro lugar, de um ambiente que deve ser utilizado, onde é possível se adquirir conhecimento, conhecer assuntos novos, se aprofundar em outros e se divertir acima de tudo. Caso a visão deturpada permaneça, os responsáveis pelas bibliotecas continuaram a usar a desculpa de que não é preciso investir no que não é utilizado.

Existe, portanto um conjunto de situações que colaboram para a não prática da leitura no Brasil. Os autores citados nesta pesquisa e as instituições que compõem o estudo de caso permitem enumerar outro conjunto de situações, mas neste caso, que colaboram para a formação de leitores. A biblioteca que conta com bons profissionais e apoio institucional pode facilmente trabalhar para mudar a visão de alguns, é o que acontece nas instituições de ensino investigadas nessa pesquisa. As percepções a respeito da biblioteca e da leitura começam a ser trabalhadas desde cedo.

Este estudo tem como objetivo verificar a existência de projetos de estímulo à leitura e à formação de leitores em instituições de ensino no Distrito Federal, com foco em 
programas desenvolvidos com crianças na fase da primeira infância. A base para a análise é a literatura da área como, por exemplo, Carol Kuhlthau, que em seu livro "Como usar a biblioteca na escola" descreve um projeto que se inicia com crianças de três anos e o processo de conhecimento do universo da biblioteca e caminha até a conclusão do ensino médio.

O texto está organizado da seguinte maneira: as duas próximas seções discorrem sobre a criança e a leitura e o hábito da leitura. Seguem-se a descrição da metodologia empregada e da análise e resultados. O texto se encerra com a seção Discussão e conclusões, onde são apresentadas e discutidas algumas das questões levantadas pela pesquisa.

\section{A CRIANÇA E A LEITURA}

Avaliar a qualidade da leitura das crianças brasileiras é extremamente problemático visto que em grande parte das vezes, o próprio aluno não foi devidamente inserido no fantástico mundo da leitura. A culpa comumente atribuída aos alunos é na verdade de seus responsáveis. A não preparação dos professores juntamente com a falta de acompanhamento dos pais gera com freqüência o comentário: "O problema aqui é que os alunos, principalmente depois dos nove, dez anos, não querem mais saber de ler" (AZEVEDO, 1999, p.1). Ler não é simplesmente decifrar o que está no papel, vai muito além, é um meio de comunicação desenvolvido entre um autor e um leitor por intermédio do código conhecido por ambos, no caso dos livros o texto empregado em determinado idioma. É preciso compreender a mensagem, perceber o que determinado livro ou história tem a lhe oferecer, fazer descobertas e compreender a comunicação existente. Os pais e os professores não ensinam este aspecto da leitura para as crianças. Logo após a primeira infância, por volta dos sete anos a leitura é definida por muitos como simplesmente uma função desenvolvida para decorar o necessário para aprovação no final do ano letivo. Esta questão é abordada na obra Como um romance de Daniel Pennac, que nos mostra que um leitor em potencial, ao começar a freqüientar o colégio se perde na obrigação de ler e passa simplesmente a detestar os livros. A questão do prazer e do lúdico é pouco abordada tanto em casa quanto nas instituições de ensino o que torna o hábito de ler praticamente desinteressante.

Este desinteresse é freqüentemente discutido por professores e pais como se uma criança, enquanto estudante, devesse obrigatoriamente ser louca por livros, como um fator biológico, intrínseco delas, entretanto quantos destes pais e professores tentam desenvolver nestes sujeitos o gosto de ler? Gosto pelo simples ato da leitura? 
Até a idade citada anteriormente por Azevedo - nove anos - é fácil dizer o que uma criança deve fazer, e do que ela deve gostar, porém a partir daí elas criam vontades e gostos próprios, e o fato dos familiares não terem tempo para se fazerem presentes nem que seja para contar uma história, acaba por substituir o contato familiar pela televisão, a qual se torna um amigo fiel. Fazer a troca do eletrônico por livros não é impossível nem fácil, entretanto a família pode trabalhar o uso da literatura com brincadeiras e torná-la interessante aos olhos da criança. Não existe a necessidade de uma substituição completa, mas trabalhar para que haja tempo para as duas atividades. A grande diferença entre a leitura e a televisão é que na TV não é necessário pensar nem questionar nada, pois as informações já estão "mastigadas", e no livro cabe além da leitura a interpretação de cada um para se concluir algo a respeito do que está contido na obra.

Cada fase do desenvolvimento dos indivíduos possui um conjunto de livros adequados que se diferenciam tanto no conteúdo quanto no padrão de apresentação, desenhos, cores entre outros. ZILBERMAN (2004, p. 11) deixa claro que o mundo da literatura infantil é vasto e composto por boas e respeitáveis obras, logo, os pais podem oferecer aos filhos desde obras lidas na infância passando por histórias orais que ouviram naquele tempo até materiais recentes. Quem não conhece Emília e Narizinho, ou nunca quis provar as guloseimas da Nhá Benta? Monteiro Lobato é o principal nome da literatura infantil brasileira é um maravilhoso exemplo que de as boas histórias não se perdem no tempo, são simplesmente repassadas. Monteiro Lobato (apud MACHADO, 2002, p. 14) "dizia que obrigar alguém a ler um livro, mesmo que seja pelas melhores razões do mundo, só serve para vacinar o sujeito para sempre contra a leitura."

Uma questão curiosa a respeito do Sítio do Pica Pau Amarelo é que os episódios podem ser adaptados por quem os conta, não existe uma história com início, meio e fim, é um mundo inteiro a ser trabalhado com a imaginação. Este momento de criação entre pai e filho gera divertimento e interação, um conhecimento íntimo de sonhos e fantasias de cada um. Não pode ser encarado como perda de tempo, é um crescimento para ambos.

No Brasil, durante o período monárquico, praticamente não havia produção literária, e o pouco que era produzido definitivamente não era voltado para o público infantil. As soluções encontradas, segundo ZILBERMAN (2004, p. 15) foram: traduzir obras estrangeiras, adaptar para as crianças o que havia ou aliar-se a tradição popular. Viagens de Gulliver, Cinderela e contos folclóricos são exemplos desta situação. 
Estas obras fazem parte do universo das histórias infantis, é provável que todo mundo já tenha ouvido pelo menos uma delas na infância. Entretanto elas não podem ser alteradas da mesma maneira que as obras de Monteiro Lobato, pois possuem contexto, enredo e um desenvolvimento conhecido. Por exemplo, o Sítio do Pica Pau Amarelo permite que se altere o universo e se crie juntamente com a história de acordo com a cultura local.

\subsection{A leitura dos clássicos}

Clássicos são obras que não se perdem. Não são livros antigos e fora de moda e sim obras que apesar do tempo continuam atuais e comumente são utilizadas em provas do tipo vestibular e em instituições de ensino nas disciplinas de literatura e língua portuguesa. Os clássicos podem ser recontados em fragmentos e passados de pai para filho, caso este pai tenha tido acesso a este tipo de material. Exemplo de histórias que podem ser trabalhadas desta forma são as aventuras de Robin Hood, esta proposta de interação familiar pode ser enriquecedor para as crianças e possivelmente estimular por meio da curiosidade a busca pela obra completa. Segundo MACHADO (2002, p.10) a memória das crianças ainda é bem disponível, então o que é "colocado" nela tem muitas chances de permanecer ali, mesmo que fique uma lembrança vaga, ainda permanecerão por toda a vida, as lembranças infantis são mais nítidas e duráveis. Estas obras são sedutoras e atraentes, se o encontro acontece cedo é possível que na juventude outras obras dos autores destes clássicos sejam procuradas, e este processo tende a ocorrer naturalmente. Autores renomados como Carlos Drummond tornaram pública sua admiração por obras descoberta na infância/juventude. Humberto Eco revelou seu encanto por Pinochio, Clarice Lispector deixou documentos a respeito da intensa felicidade que Reinações de Narizinho lhe proporcionaram. MACHADO (2002, p. 11) não pretendia somente abordar famosos que se declararam leitores desde cedo:

Prefiro chamar atenção para o fato de que todos esses diferentes livros foram lidos cedo, na infância ou adolescência, e passaram a fazer parte indissociável da bagagem cultural e afetiva que seu leitor incorporou pela vida afora, ajudando o a ser quem foi. É claro que hoje em dia o ensino é diferente e o mundo é outro. Não se concebe que as crianças sejam postas a estudar latim e grego, ou a ler pesadas versões completas e originais de livros antigos (...). (MACHADO 2002, p.11)

A questão não é propor para as crianças a leitura de filosofia, tragédias clássicas ou metafísica em obras originais, pois é claro que ainda estão fora da compreensão deles, mas sim apresentar a tradição literária que compõe os clássicos. Existem obras clássicas reescritas para o público infantil, posteriormente este leitor pode se sentir atraído pelo que há na história 
original como foi abordado anteriormente. É possível que a compreensão não seja completa, mesmo explorando os desafios e obstáculos, entretanto, clássicos devem ser revistos algumas vezes durante a vida, e em cada uma delas é possível se fazer novas descobertas. "Se o leitor travar conhecimento com um bom número de narrativas clássicas desde pequeno, esses eventuais encontros com nossos mestres da língua portuguesa terão boas probabilidades de vir a acontecer quase naturalmente depois, no final da adolescência" (MACHADO, 2002, p.12). Ou seja, uma criança que conhece alguma história, da maneira que deve ser apresentada a ela em determinada idade, posteriormente pode sentir curiosidade em ter conhecimento completo da obra, e conseqüentemente outras obras do mesmo e de outros autores. Pode se então declarar possível a formação de um leitor, este indivíduo busca obras para ler, sozinho e sem razão aparente. Simplesmente pelo prazer e curiosidade.

\subsection{Leitura na primeira infância}

A primeira infância pode ser dividida em três fases: nascimento aos dois anos, dois a três anos e finalmente três a cinco anos. SANDRONI e MACHADO (1991, p. 16) definem características básicas de cada uma destas etapas. A primeira fase é caracterizada pela observação de figuras, rimas, ritmo e repetição. Neste momento o sujeito sente necessidade de participar da história, mas a linguagem deve ser simples e as ilustrações sempre coloridas e em grandes formatos. Na segunda fase as histórias já podem ser mais longas, mas ainda há a necessidade das ilustrações. É interessante adotar livros sem texto e com muitos desenhos para que o sujeito desenvolva sua própria história baseando-se na ilustração. Começa uma relação entre as palavras e as ilustrações. Posteriormente, dos três aos cinco anos, se o sujeito foi trabalhado nas fases anteriores, é possível que já conheça vários livros e assim selecione os favoritos. Existe uma releitura intensa e a utilização dos desenhos continua necessária. A partir desta fase, a criança consegue decorar o desenho de determinadas palavras e identificá-los dentre as outras do texto, mesmo sendo analfabeta.

Depois de conhecer alguns pontos relevantes desta primeira fase do desenvolvimento infantil, é interessante escolher os livros com maior atenção. Tamanho da letra, quantidade e cores das ilustrações, personagem interessantes, extensão da história entre outros. Cada tipo de história e de estrutura são pré determinadas para uma fase, mas são apenas recomendações. 


\subsection{Psicologia}

O desenvolvimento infantil é um conjunto de processos de mudanças que ocorrem ao longo do tempo. Algumas alterações são previsíveis e outras não. Neste processo é preciso que sejam considerados os fatores biológicos, sociais, históricos e físicos dos indivíduos. Esta fase da vida é muito importante para o desenvolvimento visto que é neste período que várias estruturas se estabilizam para dar continuidade ao desenvolvimento.

O Fundo das Nações Unidas para a infância (UNICEF) aborda o seguinte aspecto:

O estímulo adequado às crianças de até 6 anos gera benefícios que vão desde o aumento de aptidão intelectual (que qualifica o acompanhamento escolar e diminui os índices de repetência e de evasão escolar) até a formação de adultos preparados para aprender a lidar com os desafios do cotidiano. Neste sentido, a educação infantil tem papel primordial. A primeira etapa da educação básica complementa a ação da família no desenvolvimento físico, psicológico, intelectual e social. Oferecida em creches ou entidades equivalentes para crianças de até 3 anos de idade e em pré-escolas para crianças de 4 e 5 anos, a atividade exige atenção especial. Estudos demonstram que é durante a primeira infância que o cérebro humano desenvolve a maioria das ligações entre os neurônios. Até os 3 anos de idade, as cerca de 100 bilhões de células cerebrais com as quais uma criança nasce desenvolvem 1 quatrilhão de ligações. O número é o dobro de conexões que um adulto possui. Aos 4 anos, estima-se que a criança tenha atingido metade do seu potencial intelectual. (UNICEF, S.D.)

Este aspecto é também discorrido por AGUIAR:

A primeira infância é um período crucial no desenvolvimento mental, emocional e de socialização do indivíduo. É até os 6 anos de idade que as estruturas físicas e intelectuais de crescimento e aprendizagem emergem e começam a estabelecer suas fundações para o resto da vida da pessoa. As estruturas seguem alguns estágios de desenvolvimento que não acontecem de maneira linear e rígida. Pode-se afirmar que os primeiros três anos de vida são fundamentais para que a criança tenha uma vida saudável e possa se desenvolver plenamente. (AGUIAR, 2007, p.1)

\section{HÁBITO}

O desenvolvimento das crianças é segundo os psicólogos em grande parte baseado no exemplo e em hábitos adquiridos na primeira infância. Estes hábitos são desenvolvidos de acordo com o dia a dia e costumes de cada grupo social. Ler nada mais é do que um destes hábitos. A falta de interesse na leitura talvez ocorra pela ausência de exemplo e estímulo na fase escolar/universitária e principalmente na primeira infância, fase fundamental para o desenvolvimento das estruturas físicas, psíquicas e habilidades. Segundo OLIVEIRA (2008 p. 1) é nesta fase que o indivíduo está propenso a desenvolver hábitos que podem ser seguidos no futuro. A leitura pode ser um deles. Notar que os livros existem, para que servem e quem 
os usa são características determinantes, este tipo de material precisa ser visto e tocado pelas crianças para desmistificar a idéia de que o livro é frágil e não deve ser retirado das estantes.

É clara a importância do contato com a literatura objetivando desenvolver o hábito de ler para uma possível formação de leitor. Quanto antes o sujeito tiver contato com o material de leitura mais facilmente poderá criar um hábito sem que esta seja associada à obrigação ou provas. A infância é um momento adequado para este desenvolvimento, pois a magia e a fantasia ainda fascinam e fazem parte do universo infantil. Outro aspecto relevante é que o livro apresenta fatos algumas vezes desconhecidos pelas crianças, despertando assim o questionamento e a curiosidade. "Ao ler uma história a criança também desenvolve todo um potencial crítico. A partir daí ela pode pensar, duvidar, se perguntar, questionar”, “(...) é preciso saber se gostou ou não do que foi contado, se concordou ou não com o que foi contado.” ABRAMOVICH (1994, p. 143).

Não é correto dizer que todas as crianças de zero a cinco anos formam um grupo homogêneo e que existe uma maneira eficaz de inserir os livros nas vidas delas. AZEVEDO (S.D.) afirma que cada criança apesar de ter estrutura física semelhante e fazer coisas bem parecidas, já possui suas experiências e peculiaridades. O meio em que vivem, a forma de educá-las e tratá-las são fatores determinantes para real avaliação sobre o desenvolvimento delas. Seria razoável que "pessoas da mesma idade [pudessem] ser consideradas indivíduos com, mais ou menos, as mesmas características e no mesmo estágio físico e neurológico" AZEVEDO (S.D.), porém o mais adequado afirmar é que existem capacidades, vivências e sentimentos que fazem parte do universo particular, está presente em uns e em outros não. $\mathrm{O}$ autor ainda completa: "Há crianças que sofreram abusos emocionais, físicos, sexuais; há traumas; há temperamentos; há sonhos; há fantasias e vivências absolutamente pessoais".

\subsection{A criança e o livro}

"Tentar criar gosto pela leitura, nos outros, por meio de um sistema de forçar a ler só para fazer prova? É uma maneira infalível de inocular o horror a livro em qualquer um" (MACHADO, 2002, p.15). O gosto pela leitura é construído gradativamente, não nascemos adorando ou detestando ler, é uma habilidade adquirida. Desde pequenos, ainda analfabetos já somos capazes de ler, porém não da maneira que o fazemos depois de alfabetizados. Nesta fase lemos imagens e objetos, posteriormente formas. Logo depois aprendemos que algumas formas são definidas, possuem nome e que sua representação significa algo, estes desenhos formam palavras, frases, textos e poemas. Então pronto! Somos capazes de conhecer um 
mundo que não nos pertence, experiências que não vivemos e idéias que não tivemos. Tudo isso esteve dentro de outras pessoas que nos permitiram conhecer. Absorver assim um pouco do que eles são, ou do que não são, do que pensam ou sentem, conhecemos mundos e seres.

Segundo SANDRONI e MACHADO (1991 p.7):

Ler é básico para o progresso na aprendizagem de qualquer assunto: velocidade e fluência para ler são essenciais. Há um processo cíclico na leitura fluente, rápida e eficiente: a criança que lê com desenvoltura se interessa em aprender se transformará num leitor capa. A capacidade de ler está intimamente ligada à motivação.

Para que a leitura se torne um hábito ela deve ser prazerosa e por esta razão existem livros para todas as idades. Consultando um dicionário, hábito significa costume, disposição exterior. Logo podemos inferir que o hábito é uma disposição adquirida pelo costume e pela repetição. A disposição para a leitura não está contida no DNA - Ácido Desoxirribonucleico é uma questão a ser trabalhada para que se desenvolva.

Em “A criança e o livro", SANDRONI e MACHADO (1991, p.9) fazem um paralelo entre o hábito alimentar e o hábito de ler. Na questão da alimentação uma criança come o que observa seu grupo social comer. Citam os autores que uma criança, mesmo que subnutrida pode rejeitar um tipo de alimento que seja desconhecido. Acerca disto, podemos substituir o alimento pela leitura. Por se tratar de um hábito, comum ou não, para uma criança o livro pode ser extremamente desconhecido se em seu círculo familiar este não for utilizado. O hábito se forma cedo, e seu desenvolvimento será muito difícil se o ambiente familiar não for propício, os livros não podem ser objetos distantes das crianças. A proximidade é necessária para que haja intimidade entre eles.

Devido à globalização, a quantidade de informação que se torna disponível a cada hora é imensa e este crescimento pode ser observado também na publicação de livros. Best Sellers são obras que fazem sucesso e que acabam por se tornar sinônimo de "bom livro". A pergunta é: bom livro para quem? O exemplo mais atual é a saga "Crepúsculo", "Lua nova", "Eclipse" e "Amanhecer" de Stephenie Meyer que conta a história de um romance entre uma mortal e um vampiro. É impressionante a proporção que estas obram tomaram. Nas revistas e jornais referentes à segunda quinzena do mês de novembro deste ano foi possível notar o frisson que a estréia do filme "Lua nova" estava causando. O mais impressionante é que grande parte do público que já leu as obras e aguardava ansiosamente pela adaptação cinematográfica são pequenos fãs. Meninos e meninas de aproximadamente doze anos. Mas será que este tipo de livro deve ser lido agora? Suspense, sangue, morte, monstros estão 
contidos na obra. Para alguns pais e estudiosos da área o importante é que a criança leia independente do material. Por outro lado, outros pais e pesquisadores acham extremamente relevante saber o conteúdo do material de leitura. Esta questão pode implicar em uma discussão, mas neste caso, além de tratamos de crianças que provavelmente ao notarem a quantidade de páginas de qualquer um dos livros citados acima desistiria da leitura. Segundo BARKER e ESCARPIT (apud SANDRONI, MACHADO 1991, p. 7) "É na infância pré escolar que se formam as atitudes fundamentais diante do livro. A criança que toma contato com o livro pela primeira vez ao entrar na escola, costuma associar a leitura com a situação escolar, principalmente se não há leitura no meio familiar (...)”. O caminho da leitura pode se tornar equivocado se os pais não acompanharem cada fase do desenvolvimento da criança com o tipo de material que deve ser lido como foi dito anteriormente. Cada idade possui obras específicas, cada leitura tem seu momento.

\subsection{Família}

A família deve se interar do desenvolvimento das crianças até que cheguem à idade escolar, entretanto não devem simplesmente colocar as crianças em uma boa escola e abandonar a educação nas mãos dos professores. A função de apresentar a leitura para as crianças pode ser desenvolvida dentro da própria casa e antes dela aprender a ler, assim a escola daria continuidade a este trabalho. De acordo com ANTUNES (apud RIBEIRO 2007, p. 6):

\footnotetext{
Para iniciar tão cedo é preciso que tudo comece no meio familiar. Aí, a escola estaria apenas dando continuidade a um processo deflagrado em casa. Mas não é isto que acontece; a família não assume esse papel de dar o impulso inicial na formação do leitor.
}

Neste momento surge a pergunta: Como apresentar a literatura para uma criança com menos de três anos? É simples, apresentar a literatura não é sinônimo de colocar a criança para ler, e sim mostrar para ela um novo universo, seja ouvindo e contando histórias conhecidas, ou desenvolvendo junto com ela novas. Como por exemplo, com a utilização de brinquedos ou de ilustrações.

O contato com histórias traz benefícios para as crianças tais como concentração, criatividade, elas ficam mais calmas, sociáveis e modificam sua forma de comunicação tornando-as mais expressivas. Este conjunto de características atua diretamente no desempenho escolar, além do que pais e filhos podem viver experiências maravilhosas junto 
aos livros. Um sujeito que cresce com o exemplo da leitura, mesmo que os pais não possuam muitos livros, observa que aquela atividade é prazerosa, afinal se fosse desagradável por qual razão os familiares manteriam sua atenção com livros? A atenção pela leitura na primeira etapa da vida pode se dar de várias maneiras. SANDRONI e MACHADO (1991) concordam com OLIVEIRA (2008) na questão que existem vários meios de se promover este encontro, isto não significa que todas as crianças que forem submetidas a este tipo de atuação dos pais vão se tornar grandes leitores e estudantes exemplares, mas com algumas atitudes é possível fornecer as ferramentas para que o hábito de ler seja desenvolvido e talvez possam adotar este hábito. São algumas delas: contar histórias sem auxilio de documentos, contar história com auxílio de livros, de gravuras, contato com livro, produção de histórias com auxílio de adulto, deixar a criança desenvolver sua própria história, permitir que a criança se coloque nos lugares das personagens entre outros.

\section{METODOLOGIA}

O objetivo específico desta pesquisa é recolher dados de programas de incentivo a leitura e a formação de leitores de duas instituições de ensino no DF com universos diferentes, uma pública e a outra privada. A questão que orientou a pesquisa foi: Faz diferença a situação da escola -- se pública ou privada -- no sucesso do programa? Para isso, foram levantados dados sobre os projetos para verificar como se desenvolveram, com que apoio institucional contaram e como são desenvolvidas as atividades e se há interação com a família.

A pesquisa é um projeto descritivo, qualitativo. Por falta tempo para se desenvolver um trabalho mais amplo, optou-se por um estudo de caso de duas instituições de ensino, uma privada e uma governamental. A coleta dos dados ocorreu por meio de entrevista semi estruturada.

Algumas escolas foram visitadas e questionadas sobre a existência de biblioteca e/ou projetos de leitura para pré determinar as possibilidades de serem escolhidas como caso de estudo. Com base nas respostas obtidas nas visitas, duas instituições foram selecionadas. A escolha da escola particular deu-se de maneira relativamente fácil. No caso das escolas do governo, a pesquisa foi mais exaustiva visto que algumas não possuem projetos, outras impõem aos alunos que levem semanalmente livros para casa, mas não trabalham com eles posteriormente e ainda existem as que aparentemente preferem não falar sobre o assunto visto que em cada tentativa de contato havia um novo impedimento. Depois da seleção houve uma 
fase preliminar na qual, as questões foram elaboradas com o objetivo de conhecer o projeto, saber a respeito do envolvimento dos pais, duração, resposta (feedback) e formalização do projeto. Novas visitas foram agendadas para a entrevista com os responsáveis e leitura dos projetos.

Primeiro caso: trata-se do Colégio Marista João Paulo II, localizado na Super Quadra Norte 702 em Brasília. É uma instituição católica que conta com matriz em Porto Alegre e filiais por todo o país. Cada escola possui características próprias, mas interage diretamente com a matriz. Existem projetos individuais desenvolvidos de acordo com as necessidades de cada escola, entretanto, estes precisam ser previamente analisados e aprovados. A escola escolhida conta atualmente com 1480 alunos do jardim 1 até o terceiro ano do segundo grau, aproximadamente 100 professores e 100 funcionários que dão apoio e suporte aos estudantes e educadores. O respondente da pesquisa é o diretor da biblioteca e autor do projeto nela desenvolvido.

Segundo caso: a instituição governamental é o Jardim de Infância da Super Quadra Norte 304 também em Brasília, possui dois projetos de leitura, ambos voltados para a primeira infância. É uma escola que comporta 204 alunos entre Jardim 1, Jardim 2 e primeira série. Fazem parte ainda 8 professores para as salas de aula, 1 professora para a sala de recursos, membros da direção, servidores, porteiros, vigias, monitores e merendeira, totalizando 30 funcionários. Neste caso como a escola não possui uma biblioteca, as atividades são desenvolvidas pela professora na sala de recursos, uma sala de aula interativa em que acontecem encontros semanais com atividades lúdicas, esta sala conta com televisão, aparelho de som, projetor, jogos e computadores.

A coleta dos dados foi realizada por meio de entrevista semi estruturada. Entretanto foi conduzida como uma conversa na qual alguns tópicos foram enfatizados. Nas visitas foi possível conhecer um pouco do universo das escolas e das atividades das crianças. A entrevista na instituição privada aconteceu em setembro deste ano. O respondente foi atencioso e buscou deixar claro todos os mecanismos utilizados por eles na formação de leitores, desde o jardim de infância até a conclusão do ensino médio. A biblioteca desta instituição possui espaços adequados às atividades do projeto e a escola trabalha em conjunto para que a execução seja plena.

A entrevista com a instituição do governo aconteceu mais tarde por fatores que infelizmente não estavam sob controle. Instituições visitadas anteriormente e que haviam autorizado a minha visita, em um segundo momento preferiram não mais se "expor" (termo 
utilizado por eles), então a pesquisa teve que ser reiniciada. A visita ocorreu também em setembro deste ano, na própria escola.

\section{DESCRIÇÃO DOS PROGRAMAS}

\subsection{Instituição Particular}

"Fio de Ariadne" é o projeto desenvolvido pelo bibliotecário do Marista, sua estrutura é bem completa e visa atender todas as etapas da vida estudantil, desde a pré alfabetização até aos alunos que estão concluindo o ensino médio, e talvez por esta razão, este foi convidado a apresentar em Porto Alegre seu projeto que possivelmente irá ser adotado em todo o país.

O programa pode ser definido como um conjunto de atividades que podem ajudar o estudante a não se perder no turbilhão de informações que se tornam disponíveis a cada hora na sociedade da informação em que este está inserido. Segundo a mitologia grega, Ariadne é uma princesa que ajuda o herói Teseu a se guiar por um labirinto em que ele precisa entrar para matar o Minotauro. Ela amarra a ponta de um novelo na entrada do labirinto e vai desenrolando-o à medida que caminham. Eles usam o fio como guia para conseguir achar a saída. Esta lenda ilustra o objetivo do projeto, preparar os estudantes para a prática de pesquisa escolar desde cedo, guiando-os da melhor forma possível.

A metodologia adotada varia de acordo com a série e/ou idade dos estudantes e aborda ainda dois aspectos: habilidade de localização e habilidade de interpretação. A primeira auxilia aos alunos a entenderem como os materiais estão organizados, e a segunda como utilizar estes materiais. As habilidades são:

Habilidade de localização:

1. Como se organiza a coleção;

2. Periódicos;

3. Audiovisual;

4. Referência;

5. Ficção e não ficção;

6. Sistemas de classificação;

7. Fontes bibliográficas;

8. Índices;

9. Internet. 
Habilidade de interpretação:

1. Avaliação e seleção;

2. Ver, ouvir e interagir;

3. Apreciação literária;

4. Elementos do livro;

5. Pesquisa e produção de texto.

O projeto é constituído de várias fases e etapas envolvidas com atividades e conhecimento, entretanto nesta pesquisa que visa apenas aspectos relativos à primeira infância, só serão citadas atividades anteriores a alfabetização, a primeira fase do projeto. Neste momento há uma preparação da criança para conhecer a biblioteca da escola e se familiarizar com as atividades. São adotadas duas etapas.

A primeira etapa é destinada a crianças próximas aos três anos, e busca-se desenvolver aspectos positivos em relação à biblioteca e aos livros. Familiariza-se o estudante com o espaço biblioteca e o que ele oferece. Se este momento for proveitoso, em pouco tempo as visitas à biblioteca serão aguardadas ansiosamente pelos estudantes. Serão desenvolvidas habilidades tais como:

1. Arranjo de coleção: sabe-se que os materiais estão em determinada ordem e é preciso ter responsabilidade na manutenção e ordem do material;

2. Técnicas de avaliação e seleção: sabe-se que a biblioteca tem livros para emprestar, que muitas pessoas usam o mesmo espaço, é preciso cuidar do material e seguir as rotinas previstas.

3. Ver, ouvir e interagir: desenvolve-se a habilidade de observar imagens, reagir ao que é visto e ouvido.

4. Apreciação literária: nota-se que existem muitos livros e muitas histórias e começam as escolhas dos personagens favoritos.

A segunda etapa busca envolver as crianças com os livros e as histórias, dependendo do desenvolvimento da turma é possível acontecer antes dos sete anos, mas normalmente não. É o momento da alfabetização em que as crianças já podem escolher seus livros e começar a lê-los sozinhas. 
O projeto desenvolvido pelo Colégio Marista João Paulo II é baseado no livro "Como usar a biblioteca na escola" de Carol Kuhlthau, em que a autora desenvolve um esquema de formação de leitores dentro das escolas com atividades lúdicas.

A atividade mais freqüente para as crianças mais novas é a "Hora do conto". Esta proposta foi retirada do livro anteriormente citado. Dentro da biblioteca existe uma sala específica para a atividade. Esta sala contém mesas e cadeiras adequadas ao tamanho dos alunos, estantes com livros infantis, fantoches e um grande tapete de e.v.a. Este ambiente recebe as turmas que são recepcionadas por uma professora devidamente caracterizada que conta a história e depois propõe uma atividade. Pode ser um desenho, uma brincadeira ou apenas um bate papo. A professora responsável também utiliza outros suportes além da voz para contar as histórias tais como teatro ou fantoches. Sexta feira também é um dia especial, as crianças devem visitar a biblioteca e selecionar um livro para levar para casa e lê-lo com os pais.

\subsection{Instituição Pública}

O Jardim da 304 norte, possui dois projetos de leitura e formação de leitores. Um deles é desenvolvido pelas professoras em sala de aula da seguinte maneira, todas as salas de aula possuem uma "biblioteca", uma pequena estante com um conjunto de livros. Alguns adquiridos pela escola/governo e outros doados pela comunidade. Semanalmente cada estudante precisa escolher um e levá-lo para casa. Como são crianças que ainda não lêem, a atividade é desenvolvida juntamente com os familiares. Acontece da seguinte forma: as crianças devem ler a história junto com os pais e depois desenvolver uma tarefa. Existem disponíveis quatro tarefas distintas com níveis diferentes (ANEXO), porém todas abordam o conhecimento a respeito da história e seus personagens. No retorno ao colégio com os livros, um aluno é sorteado para contar aos outros estudantes a história e desta forma estimulá-los. $\mathrm{O}$ aluno sorteado tem seu nome retirado da caixinha para que todos participem deste momento que contribui para a oralidade e interação.

O segundo projeto é completo e bem desenvolvido. Foi elaborado pela professora da sala de recursos. A partir de uma história infantil sobre uma joaninha, ela começou a desenvolver brincadeiras e tarefas todas baseadas no livro. As crianças além de ouvir, conversar e desenhar sobre as personagens fazem dobraduras, chaveiros, caixinhas entre outros além de desenvolverem as atividades em uma sala especialmente decorada. A professora conta a história inicial e posteriormente em outros encontros conta outros episódios a respeito da joaninha utilizando um painel de feltro com peças colantes. Esta "brincadeira" 
tomou grandes proporções na escola, atualmente a responsável é conhecida como a "professora joaninha".

\section{ANÁLISE DAS RESPOSTAS}

A análise dos dados foi embasada na comparação das respostas das instituições visitadas. A primeira pergunta questiona aos responsáveis com que idade a criança começa a participar do projeto e como ele funciona. Nas duas escolas a aproximação com os livros e o momento de leitura é iniciada por volta dos três anos de idade. Ainda não leitores já gostam de ouvir histórias as quais já podem ser trabalhadas com conversa, desenho, colagem entre outros. Na instituição privada ele é mais completo, nesta idade busca oferecer para a criança conhecimento acerca da biblioteca, o que ela oferece e como funciona além das histórias Hora do Conto. Este momento é semanal e acontece em uma sala decorada especialmente para esta finalidade. As crianças são dispostas no chão em círculo e uma professora, devidamente caracterizada, conta uma história. Posteriormente eles conversam sobre personagens, ambientes da história, moral e desenvolvem alguma atividade prática. $\mathrm{Na}$ instituição pública existe semanalmente um momento no qual cada aluno escolhe um livro para levar para casa juntamente com uma tarefa. Na semana seguinte é sorteado um aluno para contar para os colegas sobre a história que levou. Desta forma eles perdem a timidez, desenvolvem a oralidade e divulgam a história podendo provocar interesse nos colegas. $\mathrm{O}$ aluno que foi sorteado tem seu nome retirado da urna para que desta forma todos participem. Ainda na instituição do governo o projeto da Joaninha também possui encontros semanais na sala de recursos. A professora "Joaninha" propõe alguma atividade prática baseada na história contada, normalmente são atividades ligadas às artes, tais como pinturas, dobraduras e colagem.

A segunda pergunta é acerca da participação dos pais. Nas duas instituições existe participação de familiares. Os estudantes ainda não sabem ler, por isso precisam que lhe contem a história para que eles possam desenvolver a atividade proposta. No caso do colégio Marista não há atividade para casa, elas são desenvolvidas na biblioteca com os professores ou em sala de aula. A participação dos pais pode colaborar para o desenvolvimento das crianças, assim é importante que a escola elabore tarefas para serem desenvolvidas em casa, com a família. Apesar do projeto da escola privada ser mais elaborado e completo, neste aspecto deixa a desejar. 
Em seguida buscou-se informações sobre a duração dos projetos e o feedback. "Fio de Ariadne" (projeto da escola particular) é iniciado no jardim de infância e se estende até o terceiro ano do segundo grau. É um projeto mais extenso e completo, visa à formação do leitor em várias etapas. Já na escola do governo a duração se estende até a conclusão do jardim de infância, aproximadamente três anos, quando o aluno é transferido para outra escola. O feedback é avaliado de acordo com o desenvolvimento e a evolução dos alunos em ambos os colégios. As tarefas propostas pela escola pública possuem uma hierarquia de dificuldade (ANEXO). Na escola particular os professores acompanham e avaliam o desenvolvimento e os pais ao final de cada ano recebem um questionário que engloba questões acerca de todo o colégio, incluindo o projeto de leitura, e desta maneira é também avaliado.

Os projetos estão devidamente formalizados em suas respectivas instituições. No caso do Marista o projeto foi encaminhado à matriz, pois há a possibilidade de que seja implantado em toda a rede. Na rede púbica foi descrito e aprovado pela direção da escola.

Observando as atividades desenvolvidas nas duas instituições é possível notar que são projetos que visam a interação dos estudantes com os livros e podem ser considerados um bom começo no processo de formação de leitores se consideradas corretas as atividades sugeridas pelos autores anteriormente mencionados. No caso da instituição pública o projeto desenvolveu-se naturalmente com a idéia e iniciativa de uma das professoras e posteriormente foi se expandindo até se tornar parte do currículo e ser aplicado em todas as turmas. No outro caso, na escola particular, o projeto é baseado no livro "Como usar a biblioteca na escola", de Carol Kuhlthau, no qual ela apresenta um programa de atividades a serem desenvolvidas. A questão financeira é relevante e poderia ser um caráter de diferenciação na qualidade dos projetos, mas surpreendentemente neste caso não. É claro que existem algumas distinções de materiais e de recursos, porém é possível se notar nas fotos (ANEXO) que nos dois casos o espaço físico e as atividades são adequados.

\section{DISCUSSÃO E CONCLUSÃO}

A leitura é um hábito que pode contribuir intimamente com o desenvolvimento social e escolar das crianças. Esta formação é normalmente atribuída aos professores e instituições de ensino, entretanto a participação dos familiares contribui muito para a descoberta de um novo mundo. Infelizmente devido à correria do dia a dia, em alguns casos este tipo de participação pode deixar a desejar. A primeira infância, fase desde o nascimento 
até aproximadamente sete anos, é a mais adequada para o desenvolvimento de hábitos a serem levados por toda a vida. Os autores citados na revisão bibliográfica nos deixam claro que a prática da leitura, ou o hábito de ler deve ser preferencialmente inserido no universo infantil logo nesta etapa. Contudo existem meios de se desenvolver este hábito e aspectos que são essenciais tais como o tipo de material em cada fase do desenvolvimento das crianças. Nesta primeira fase da vida os métodos devem ser preferencialmente lúdicos e necessitam da participação de adultos, preferencialmente os pais. Porém não existe um padrão para a formação de leitores, não é possível desenvolver uma técnica que dê certo com $100 \%$ dos sujeitos. Principalmente se tratando das crianças, a leitura tem que ser praticamente uma brincadeira, nunca pode parecer uma obrigação, muito menos ser um sacrifício. Existe a necessidade de ser prazerosa e divertida. O mundo literário infantil é vasto e apesar de alguns materiais caros ou de má qualidade, é possível se encontrar obras mais em conta e qualificadas para tornar as crianças curiosas e mais atraídas pela leitura.

O estudo de caso permitiu uma comparação entre os dois universos aparentemente distintos, o da escola pública e o da escola privada, entretanto é notável a semelhança dos programas de leitura. Nos dois casos a idealização dos projetos desenvolvidos atualmente, está centrada no empenho de uma pessoa. A idéia não partiu de uma proposta feita pelas instituições de ensino, mas sim por um de seus funcionários. Isto não quer dizer que as escolas não ofereçam o apoio necessário, tanto de material quanto de funcionários, apenas que o início, a idéia partiu de um segmento externo à direção pedagógica. Este aspecto leva à reflexão das seguintes questões: haveria projetos de leitura elaborados se estes funcionários não propusessem? E ainda: os projetos de leitura continuarão quando estes não fizerem mais parte do grupo de funcionários das instituições? Para o primeiro questionamento, é possível que a resposta seja não. As escolas continuariam com o antigo processo em que as crianças levam um livro para casa, fazem a leitura no fim de semana e talvez alguma tarefa, mas a questão lúdica e o universo mágico não estariam presentes. A segunda questão é um pouco mais complexa. No caso da instituição governamental este ponto foi levado em consideração e a resposta obtida foi: "Com certeza não da mesma forma. A professora que substituirá futuramente a Joaninha poderá ler tudo que foi documentado a respeito do projeto e dar continuidade com os mesmos objetivos, mas o empenho e dedicação dependem de cada um" (Funcionária). A professora Joaninha é uma figura ímpar, a maneira como ela desenvolve seu projeto e fala sobre ele demonstra orgulho e entusiasmo. É possível que outra pessoa consiga dar continuidade ao projeto, mas os sentimentos provavelmente não serão os mesmos, a Joaninha sonhou, idealizou e desenvolveu desde a programação até atividades, o projeto faz 
parte dela. Transferir o dever acerca do projeto é possível, o sentimento não. Considerando então a instituição privada, o projeto foi apresentado à matriz e provavelmente será implementado em todo o país, desta maneira independentemente do funcionário o programa deverá ser seguido. Novamente o aspecto relativo ao entusiasmo é um critério as ser abordado. Em cada escola, apesar do projeto ser bem semelhante, o desenvolvimento pode ser diferenciado. Educadores que por ventura substituam os atuais profissionais dos projetos, podem trabalhar com paixão pela leitura e desenvolver o projeto com mais amor e dedicação, fazer alterações e colocar nele suas peculiaridades. Por outro lado alguns professores podem apenas aplicar rigorosamente o que o projeto propõe e desta forma provocar o desinteresse dos alunos e dos funcionários participantes. 


\section{REFERÊNCIAS}

ABRAMOVICH, Fanny. Literatura Infantil: gostosuras e bobices. São Paulo: Scipione, 1994.

AGUIAR, Gabriela Azevedo de et al. Breve Panorama sobre a Primeira Infância no Brasil.

Disponível em: <http://www.promundo.org.br/PrimeiraInfancia/Breve\%20Panorama $\% 20$ sobre\%20a\%20 Primeira\%20Infancia\%20no\%20Brasil\%20-\%2017.05.2007.pdf $>$. Acesso em: 23 mar. 2009.

AZEVEDO, Ricardo. A literatura, o chamado "universo" e a vida mesmo. 1999 p. 1

Disponível em: < http://www.ricardoazevedo.com.br/Artigo04.htm>

Acesso em: 23 mar.2009

AZEVEDO, Ricardo. Livros para crianças e literatura infantil: convergências e dissonâncias. 1999 p. 1

Disponível em: <http://www.ricardoazevedo.com.br/Artigo01.htm>.

Acesso em: 23 mar. 2009.

CUNHA, Maria Antonieta da. Acesso à leitura no Brasil: considerações a partir da pesquisa. In: Retratos da leitura no Brasil. São Paulo: Imprensa Oficial, 2008. p.12-17.

Disponível em:

<http://www.cerlalc.org/redplanes/boletin_redplanes/documentos/Noticia1/Retratos_2008.pdf $>$. Acesso em: 24 nov. 2009;

KUHLTHAU, Carol. Como usar a biblioteca na escola: um programa de atividades para o ensino fundamental. Tradução e Adaptação Bernadete Santos Campelo et. al.. Belo Horizonte: Autêntica, 2002. (Coleção Formação Humana na Escola).

MACHADO, Ana Maria. Como e por que ler os clássicos universais desde cedo. Rio de Janeiro: Objetiva, 2002.

OLIVEIRA, Maria de Fátima Silva. Estimulando o gosto pela leitura na educação infantil. In: CONGRESSO DE EDUCAÇÃO DO SUDOESTE GOIANO: INFÂNCIA SOCIEDADE E CULTURA., 24., 2008, Jataí. Artigo. Jataí: UFG, 2008.

Disponível em: <http://www2.jatai.ufg.br/ojs/index.php/acp/article/viewArticle/236>.

Acesso em: 17 abr. 2009

PENNAC, Daniel. Como um romance. Rio de Janeiro: Rocco, 2008. 152 p. (L\&PM Pocket).

RIBEIRO, Adriana de Barros. O papel da biblioteca escolar na formação do leitor. 2007. 17 f. Monografia (3) - Curso de Biblioteconomia, Departamento de Ciência da Informação e Documentação, Universidade de Brasília, Brasília, 2007.

SANDRONI, Laura C; MACHADO, Luiz Raul. Criança e o livro: guia prático de estímulo à leitura. São Paulo: Ática, 1991. 
SILVA, Ezequiel Theodoro da. O ato de ler: fundamentos psicológicos para uma nova pedagogia da leitura. 10 ed. São Paulo: Cortez, 1981.

UNICEF (Fundo das Nações Unidas para a Infância)

Disponível em: http://www.institutocamargocorrea.org.br/infancia.aspx

Acesso em: 02 jun. 2009

ZILBERMAN, Regina. Como e por que ler a literatura infantil brasileira. São Paulo: Objetiva, 2004. 176 p. (Como e porque ler). 


\section{ANEXO: ENTREVISTA}

1. Com que idade as crianças são iniciadas no projeto de formação de leitores e como ele é desenvolvido?

2. Existe participação dos pais? Como ela acontece?

3. Qual a duração do projeto desenvolvido?

4. Como é avaliado o desenvolvimento/feedback?

5. O projeto é formalizado na instituição? De que forma? 
ANEXO: INSTITUIÇÃO PRIVADA - MARISTA JOÃO PAULO II


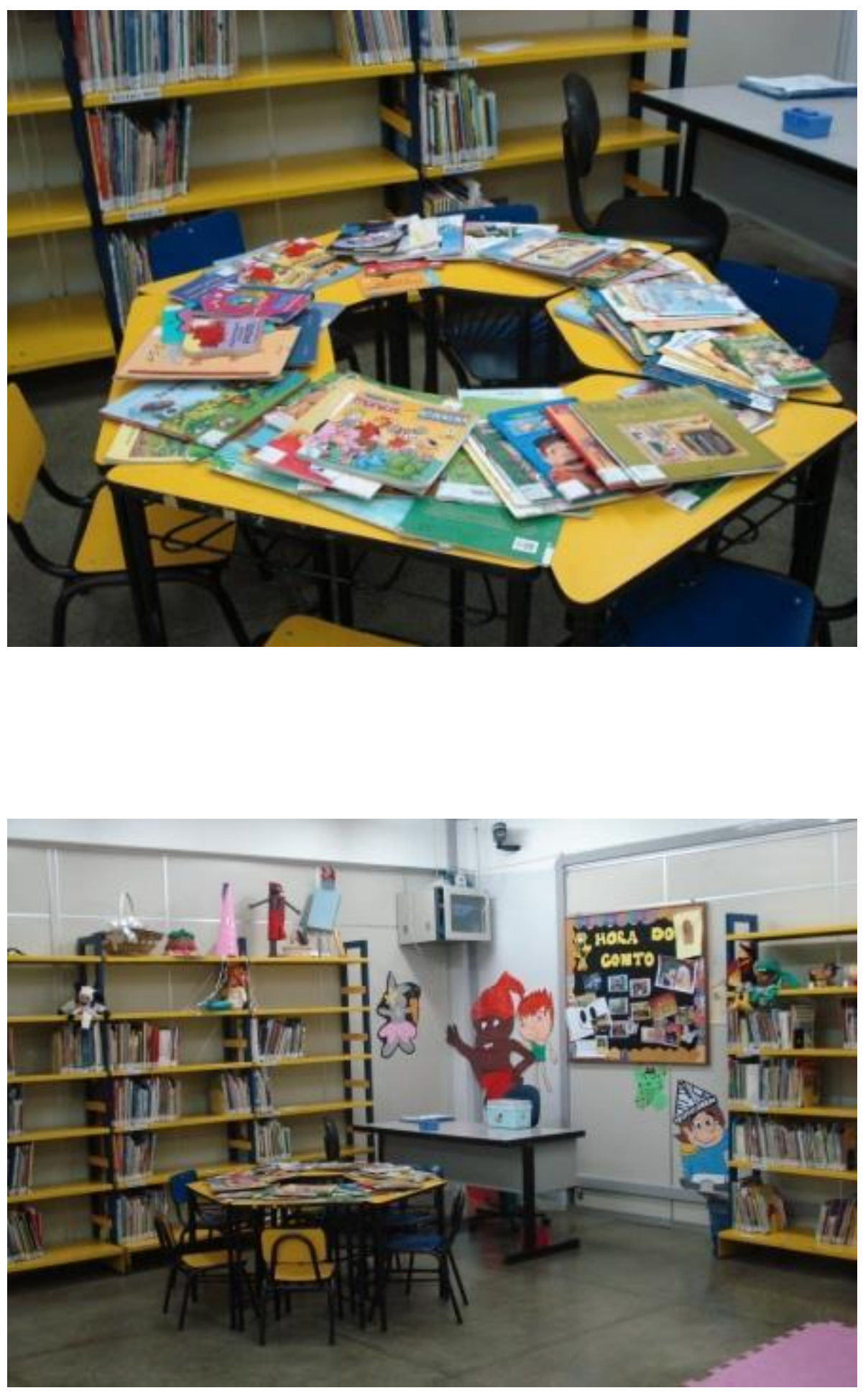

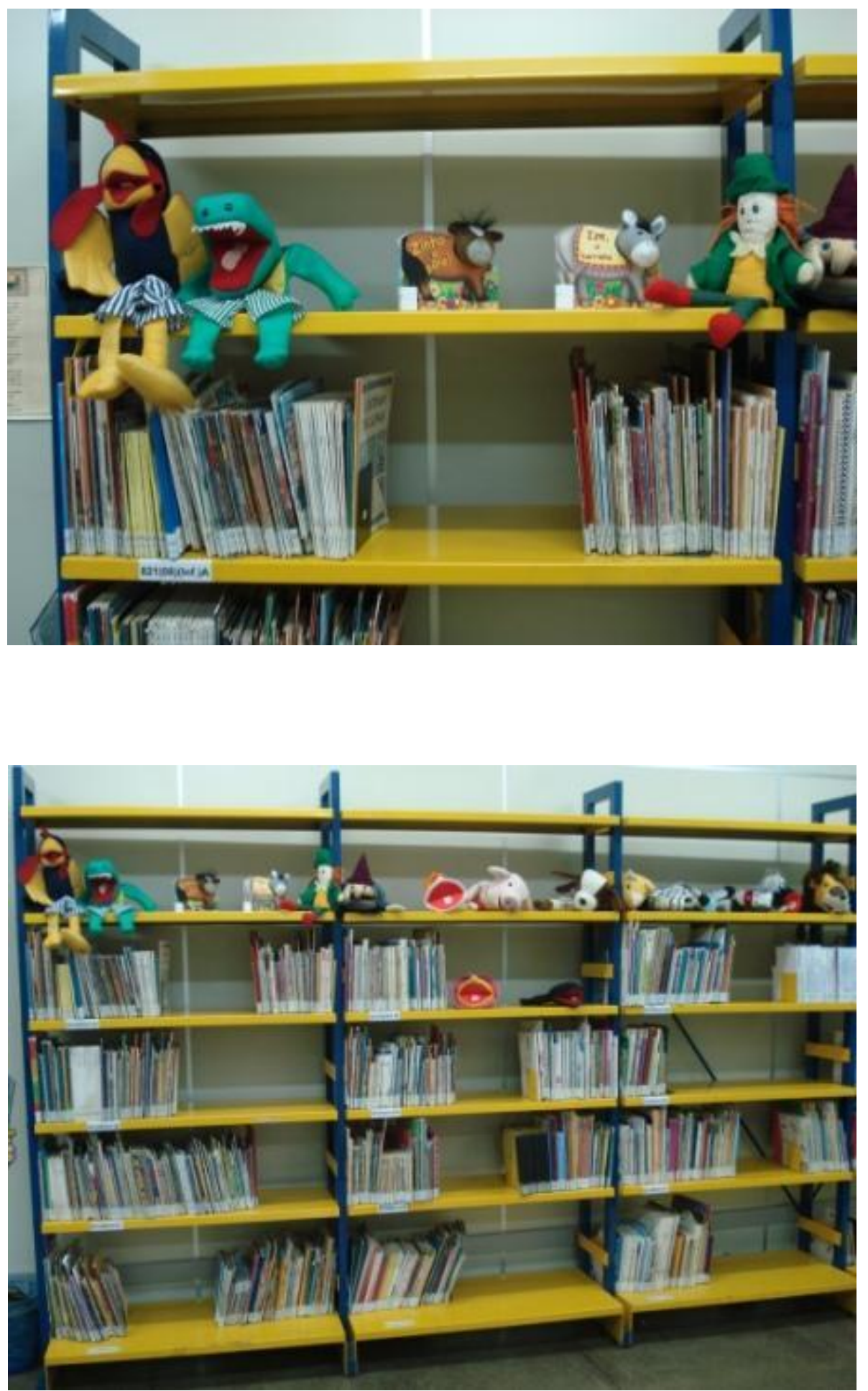

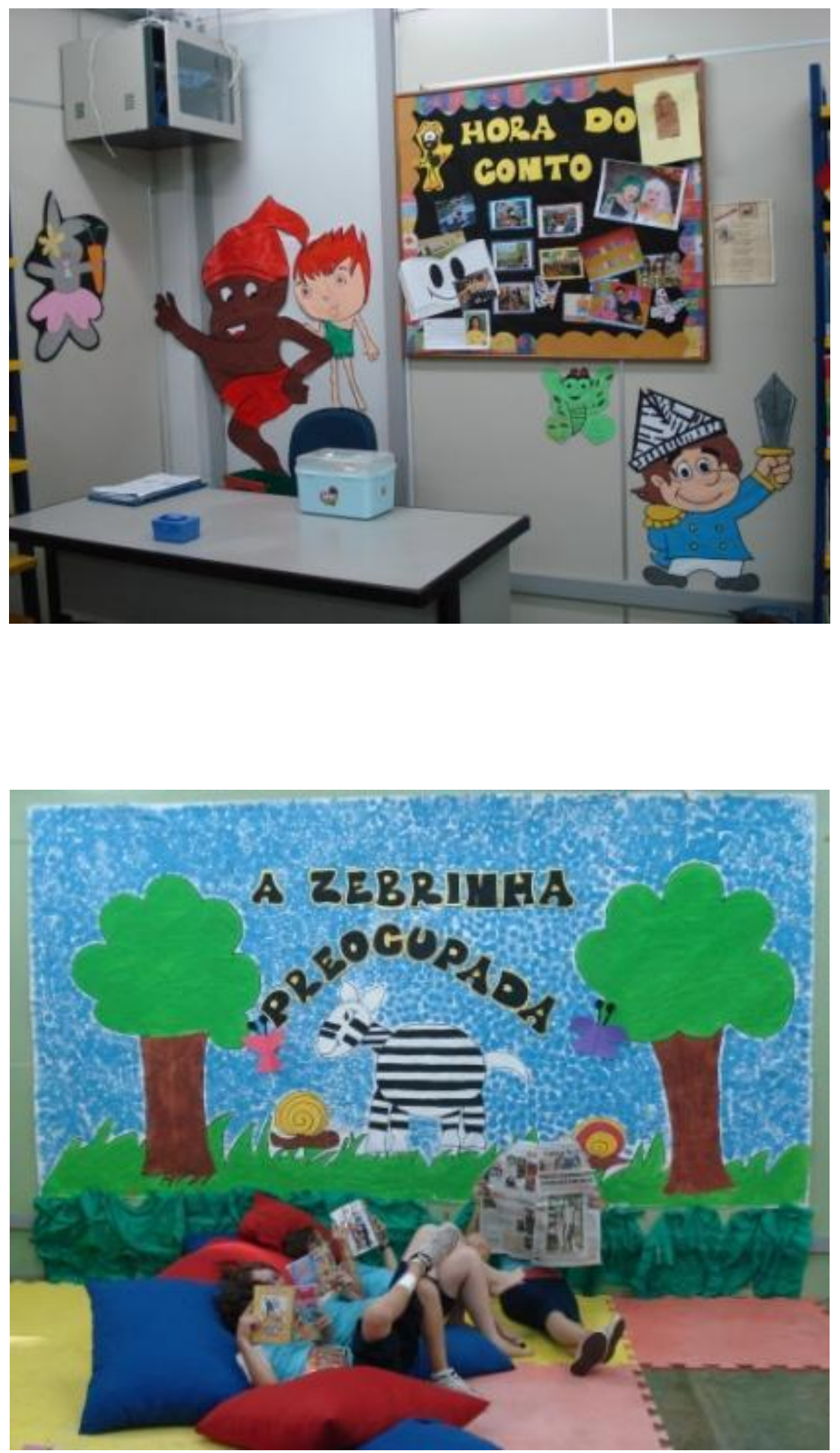

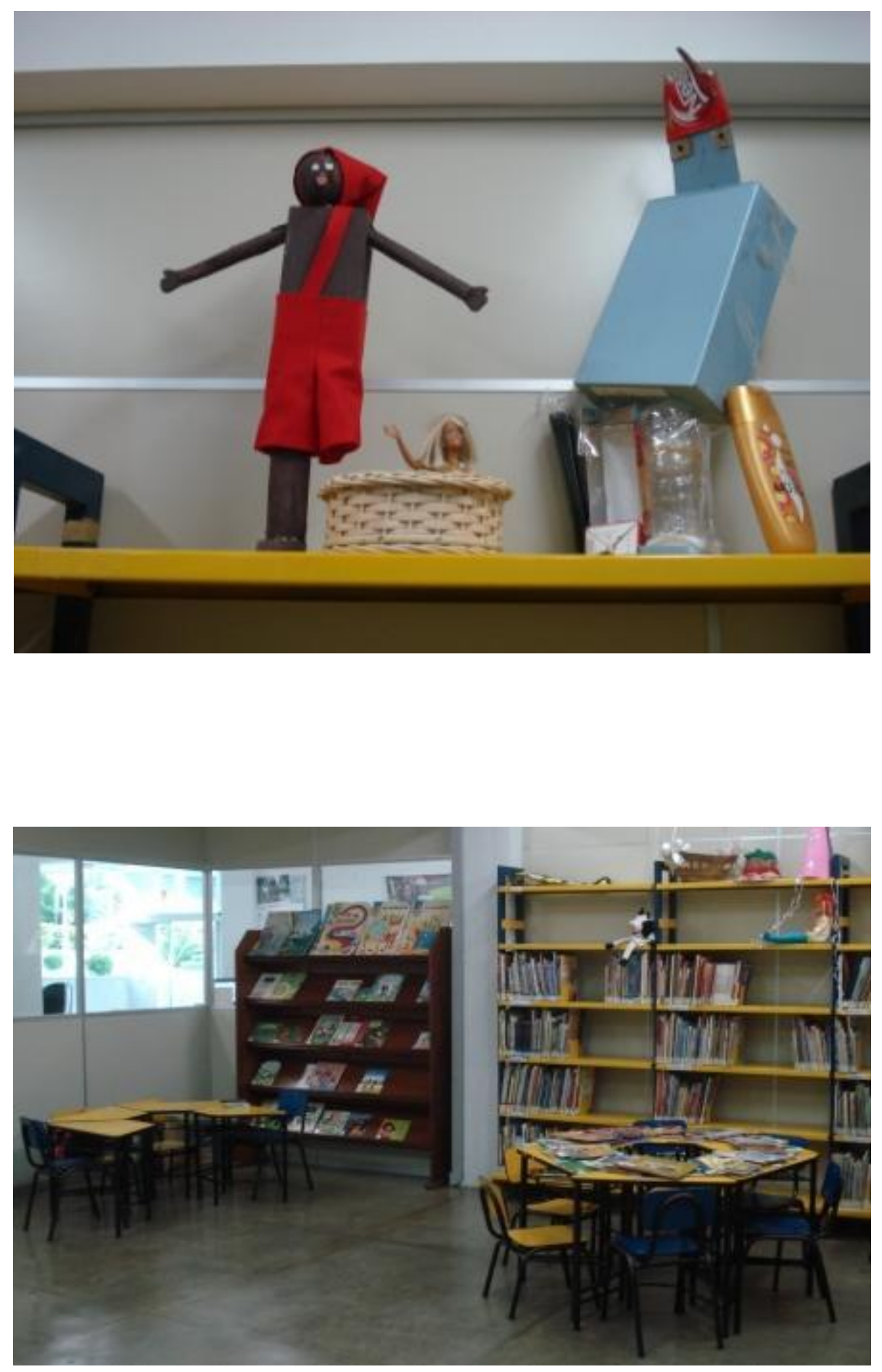


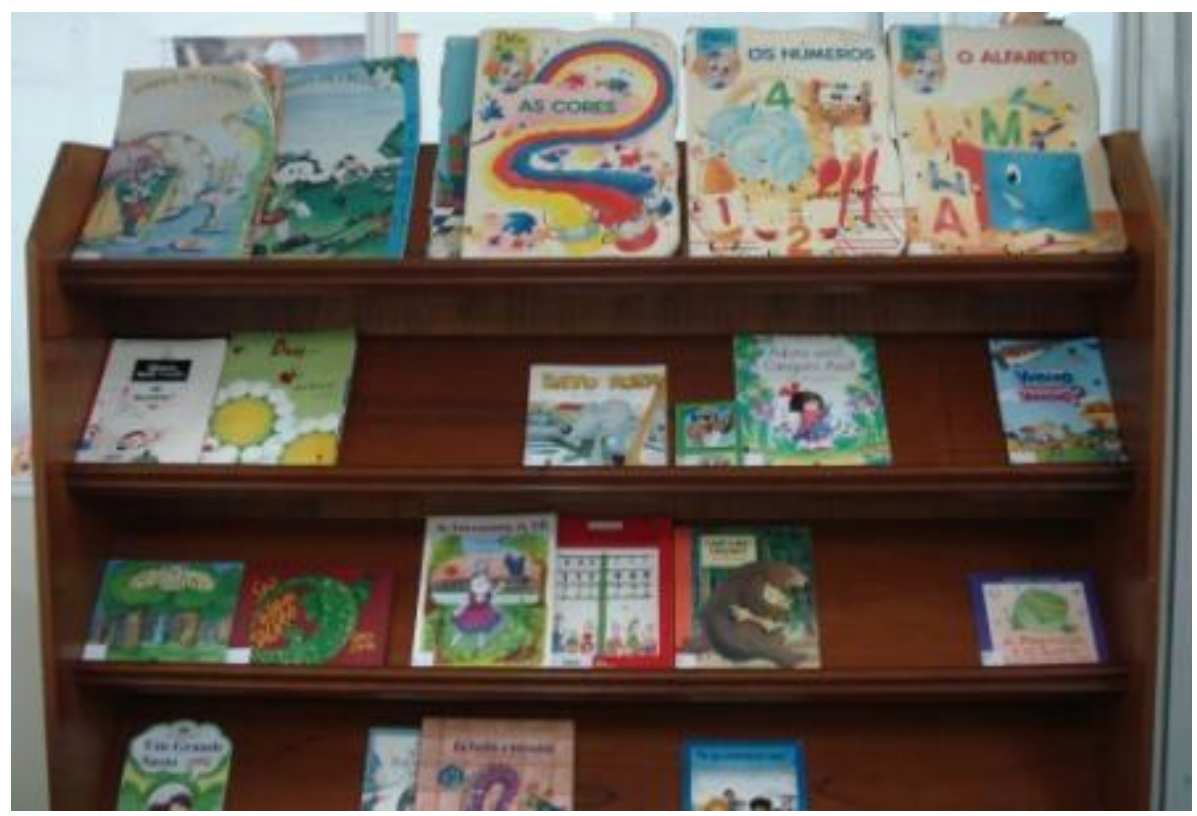


ANEXO: INSTITUIÇÃO PÚBLICA - JARDIM 304 NORTE
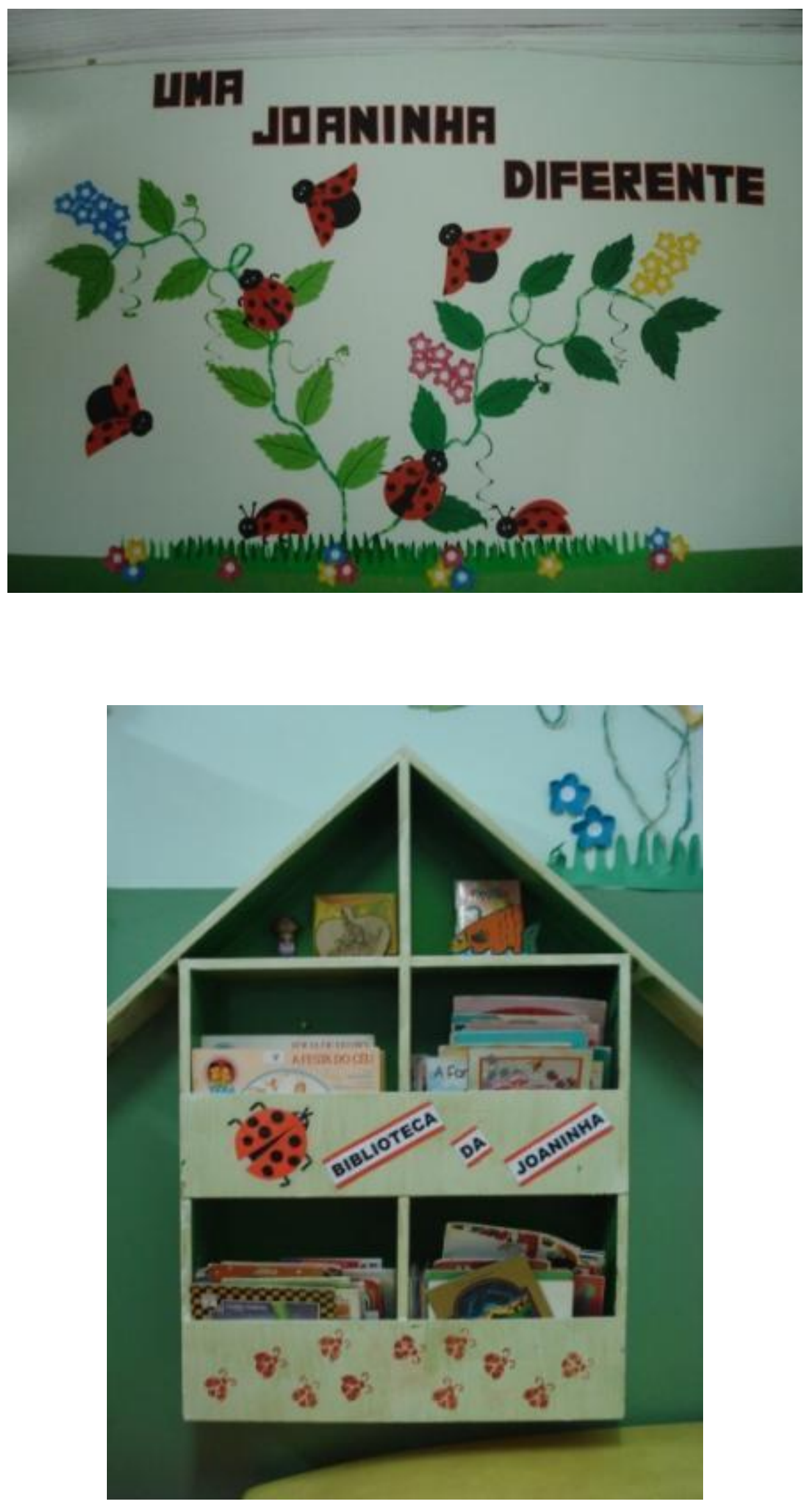

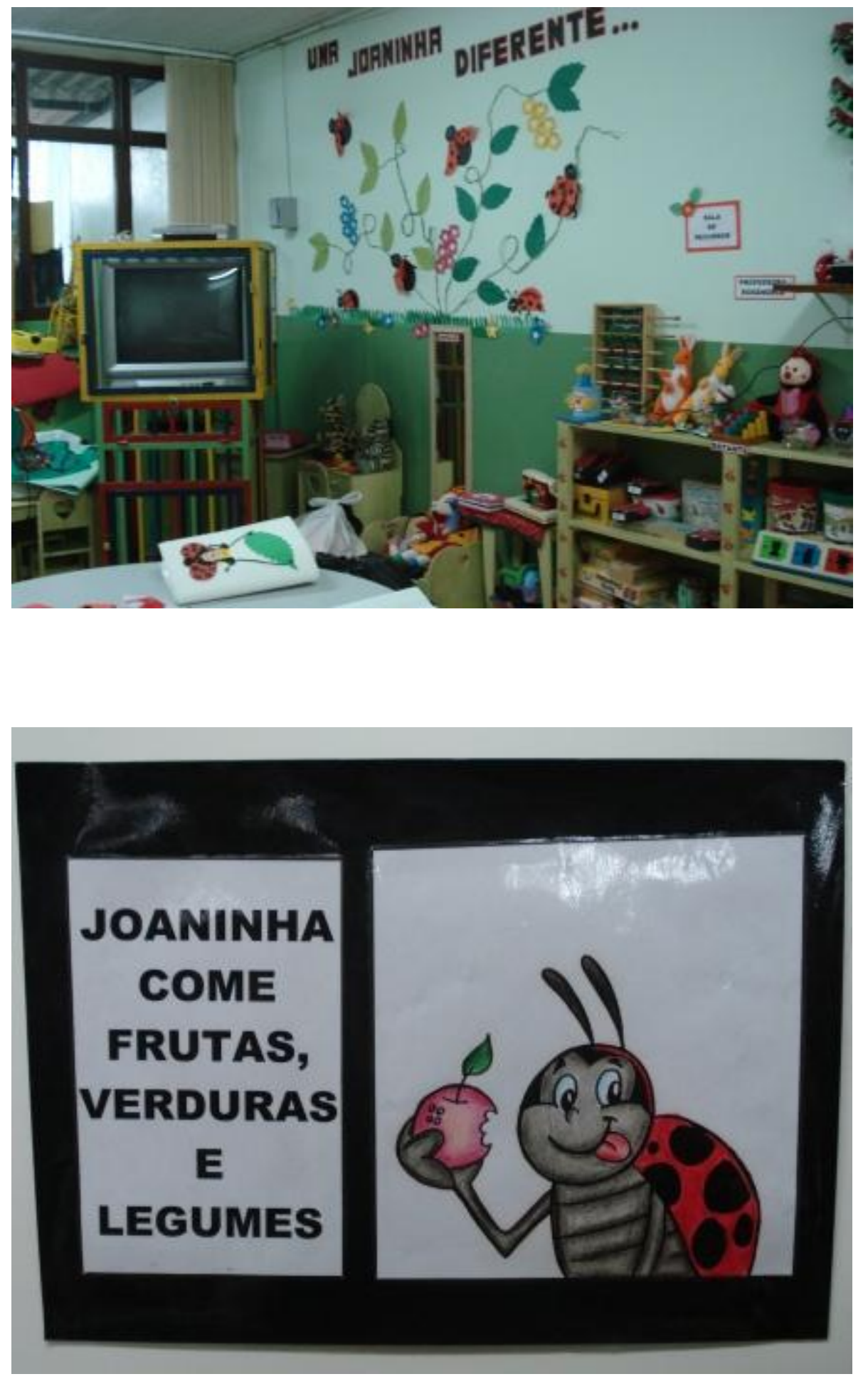

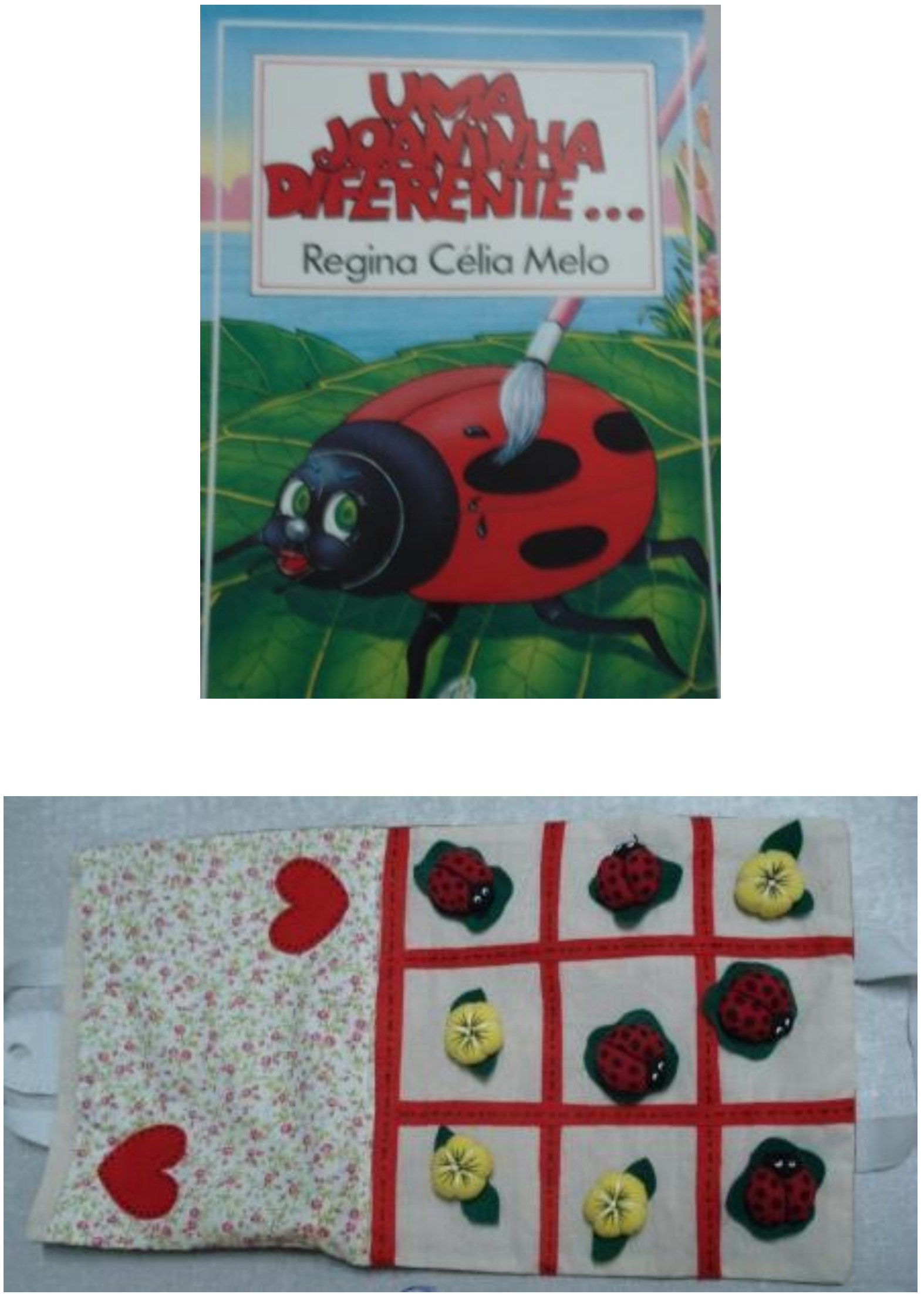

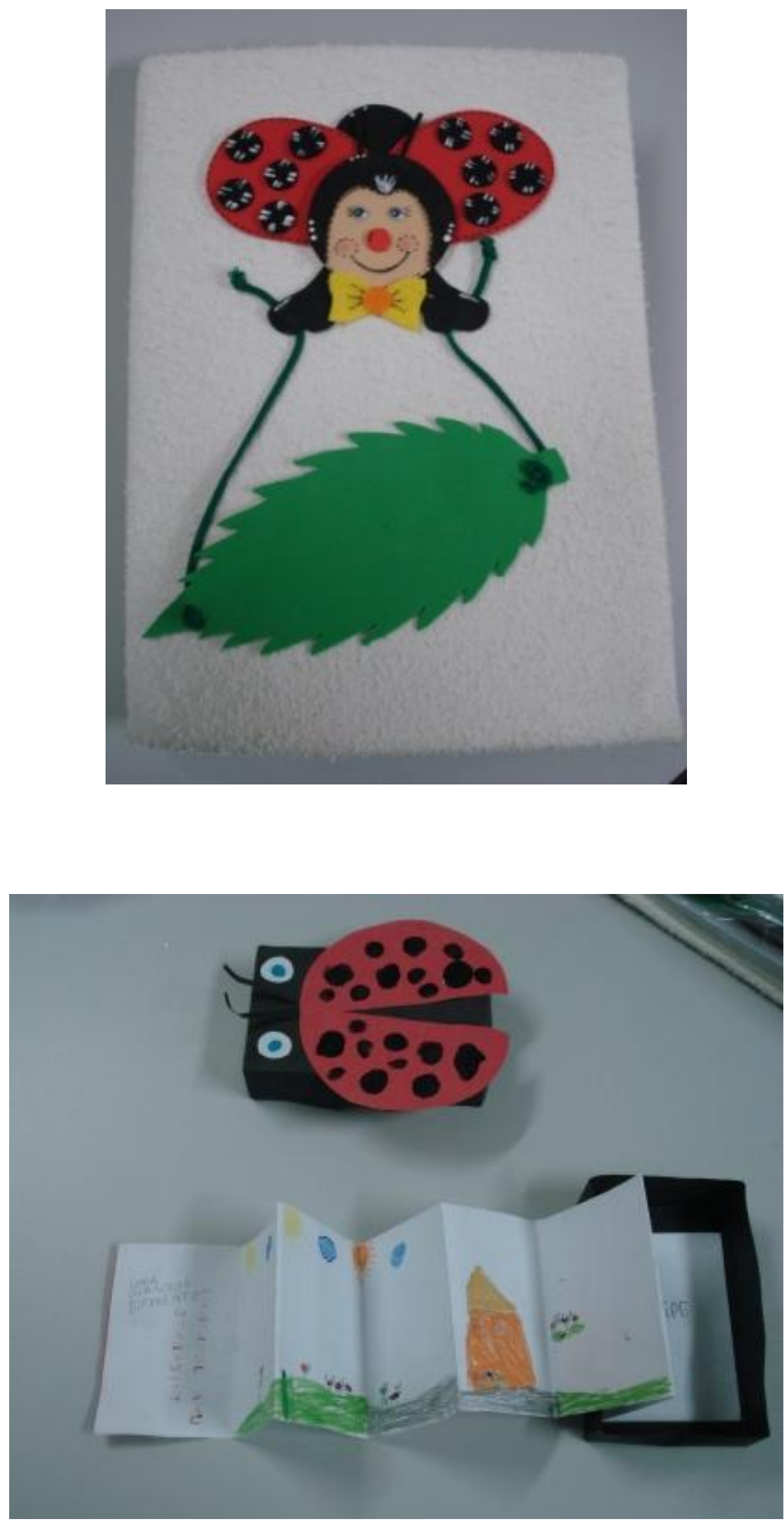

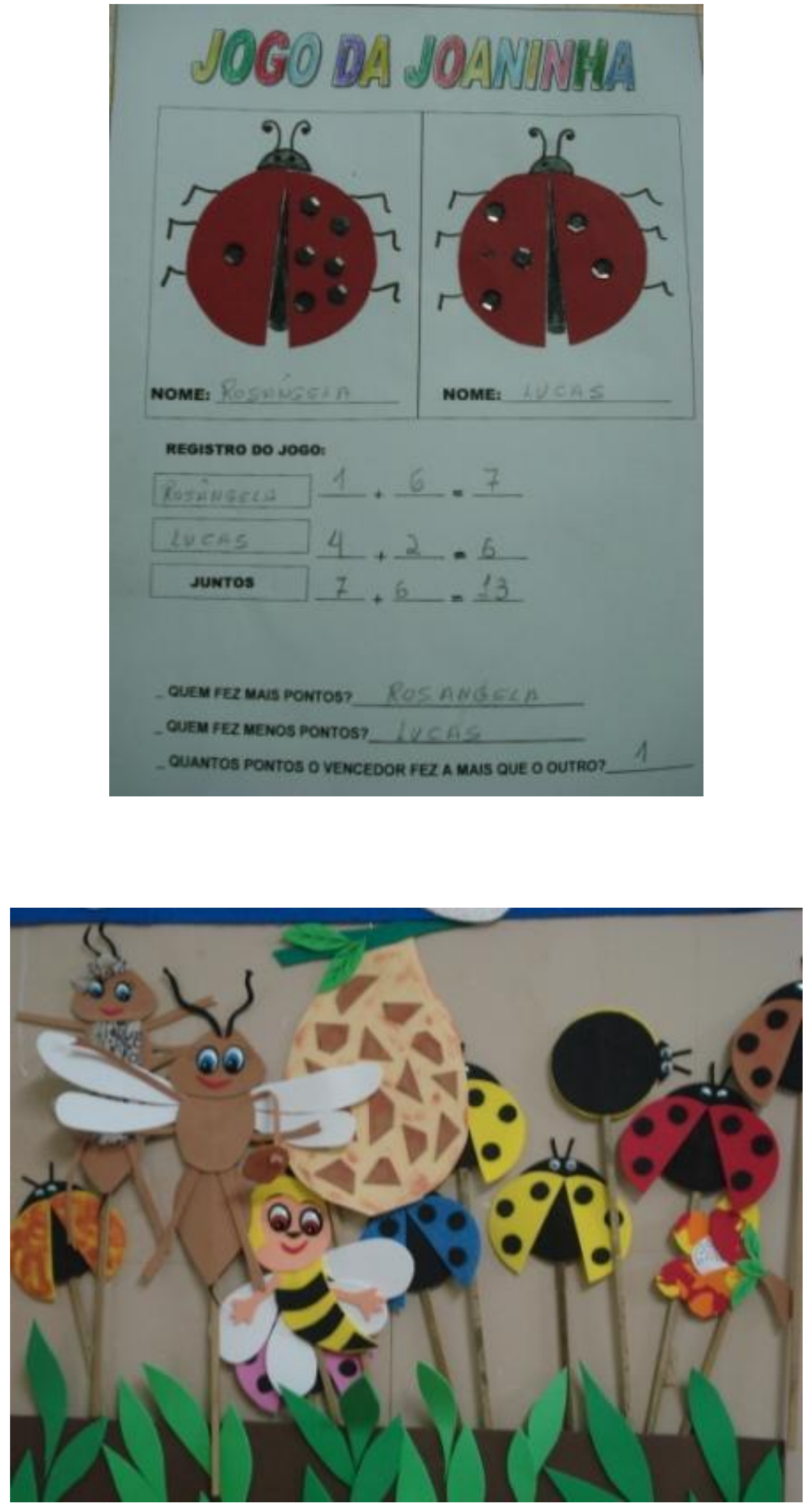
CAIXINHA DA JOANINHA

2. Periodo vespertino / 5 anos

Professora: Ana Josefa

Técnica

Utilizada:

-Pintura a dedo

Materiais:

- Cola colorida

- Rolinho de papel higiênico

- Fita preta tnt
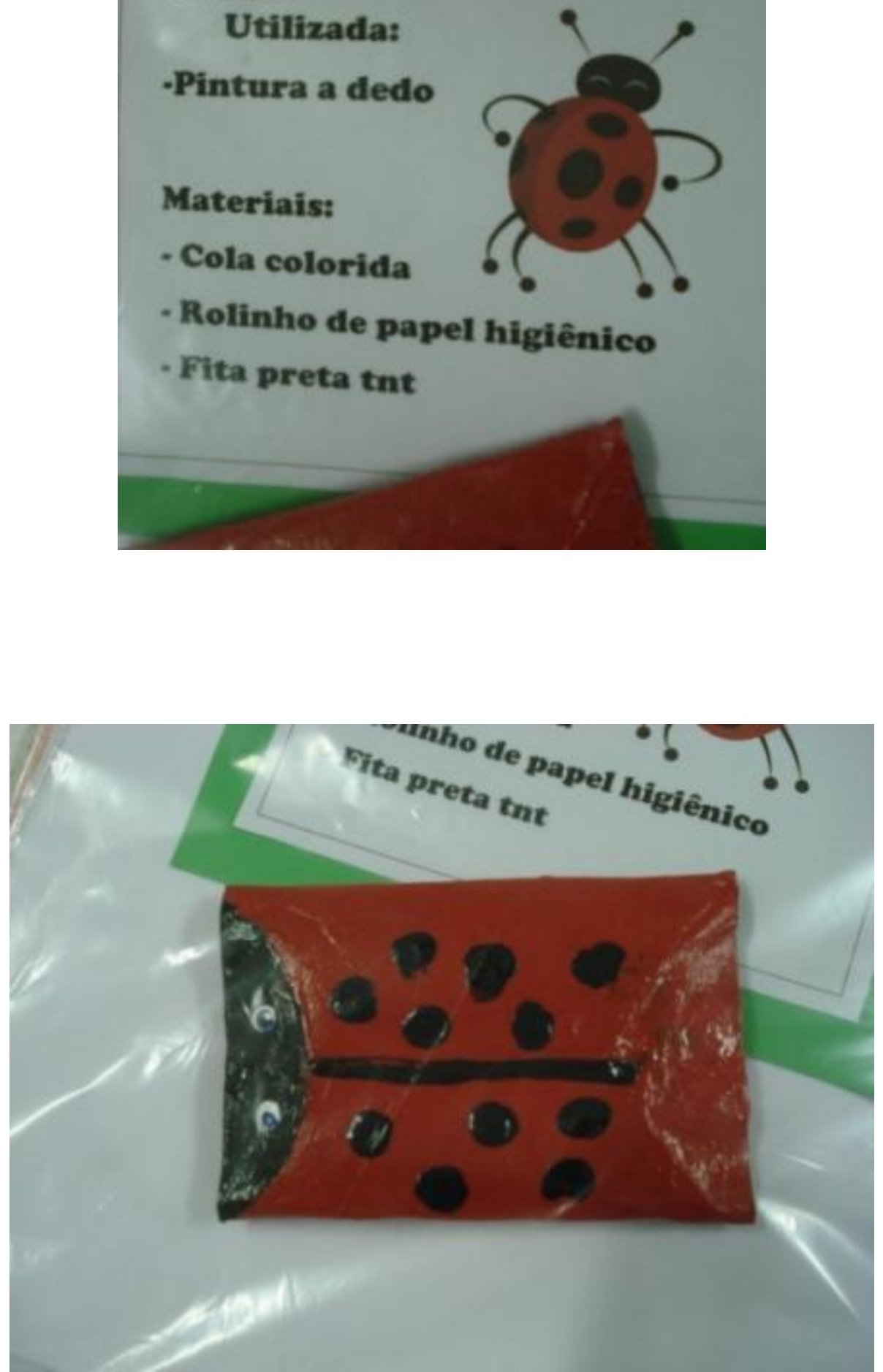

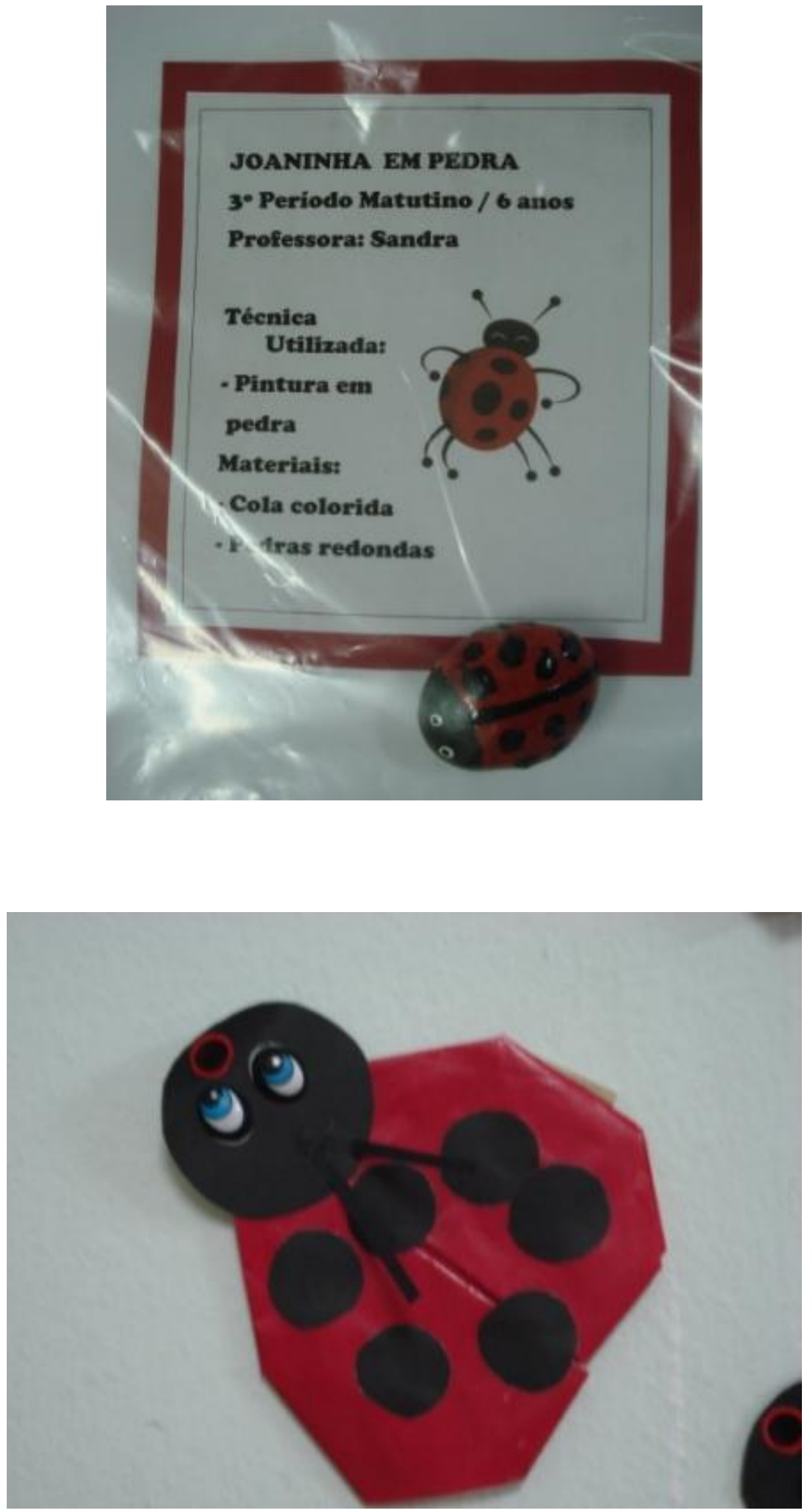
FICHA DE LTERATURA

NOAE DO LVR: alice no pris deas maral thas MOME DO AuTOR: Colecao mundo magico

DESEMHE OS PERSONAGENS DA HISTORA:

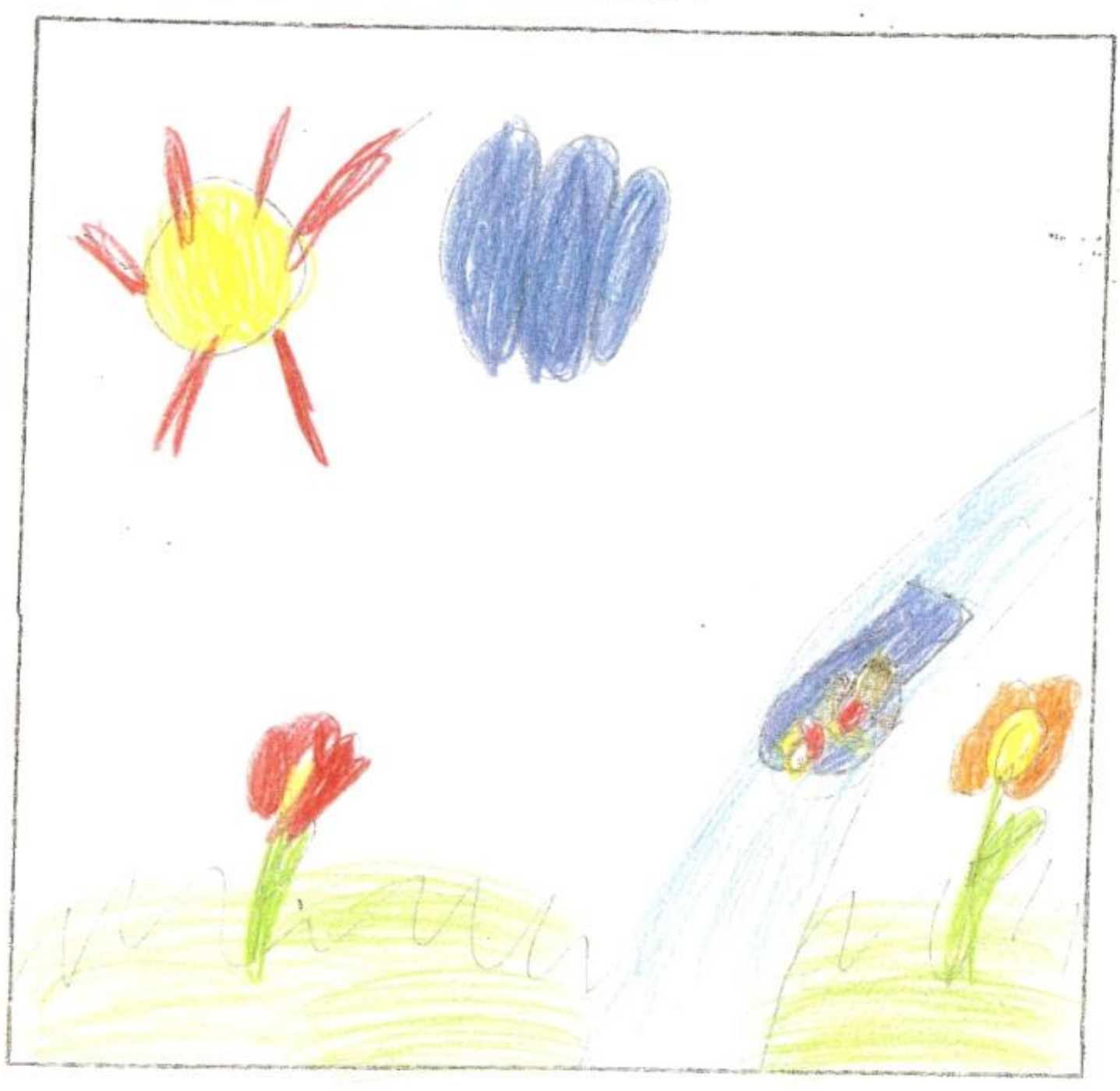


FICHA DE LITERATURA

NOME DO LIVRO: confu são no jovdinn NOME DO AUTOR: ferrulecho verdolin fillno

DESENHE AS PARTES DA HISTÓRIA:

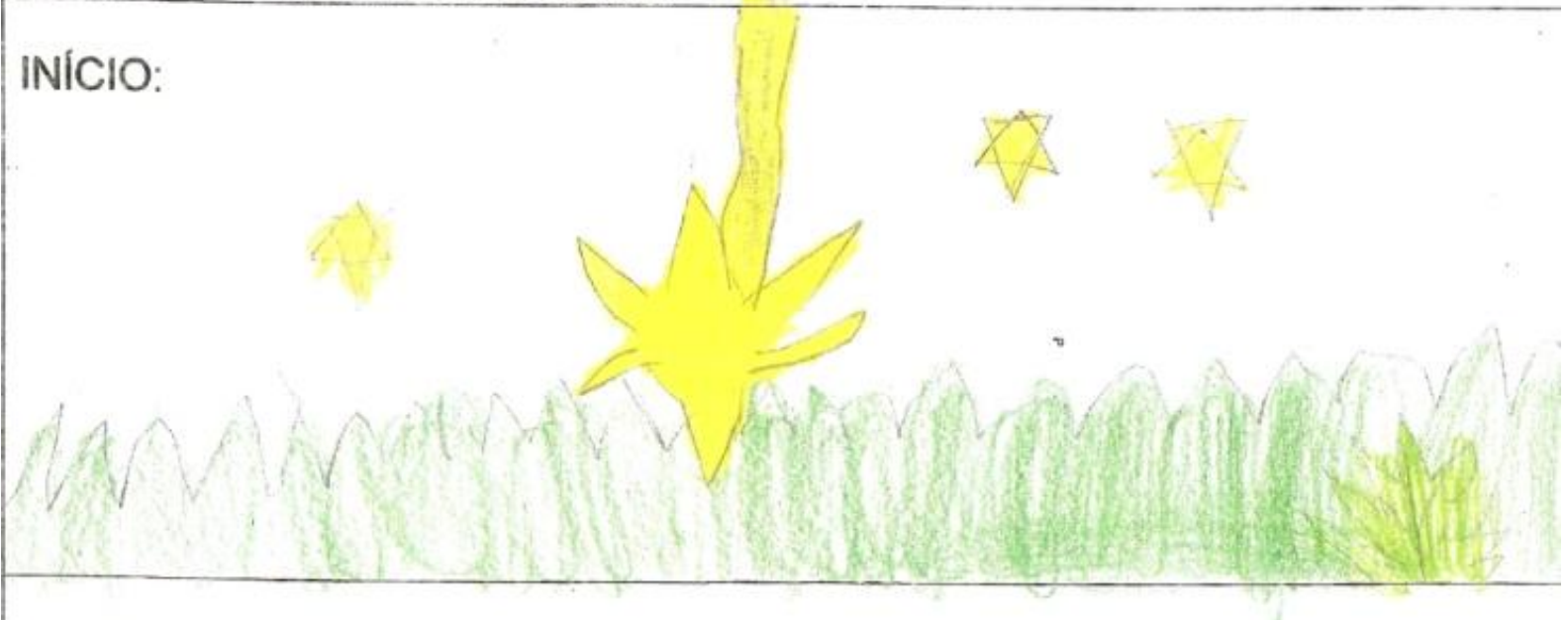

MEIO:

INVENTE UM FINAL DIFERENTE:
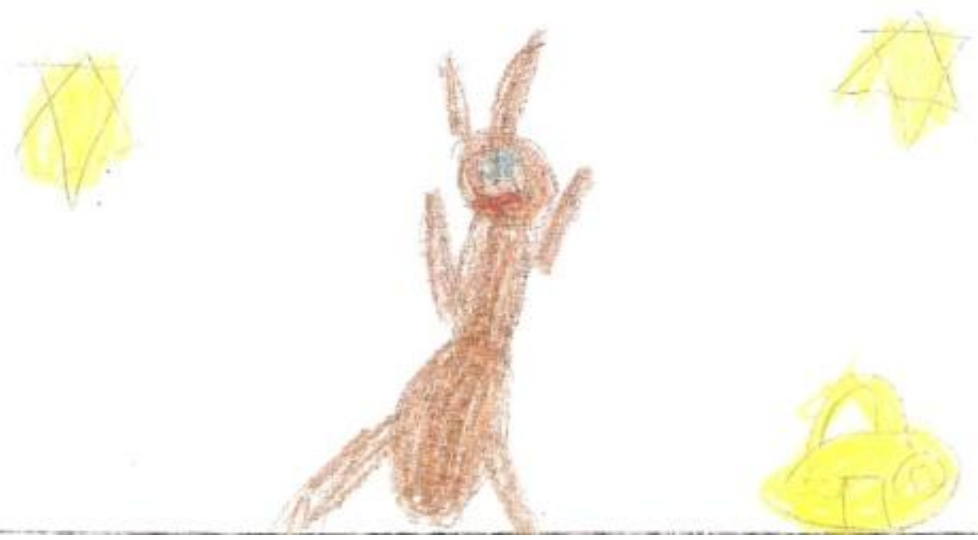
FICHA DE LITERATURA

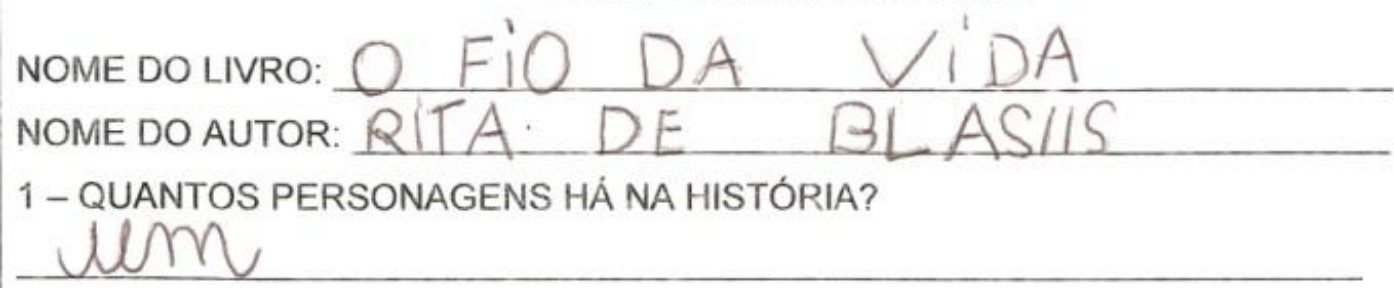

2 - QUAL O NOME DO PERSSONAGEM PRINCIPAL?

Wm pintinho

3 - QUAL A ATUAÇÃO DO PERSONAGEM PRINCIPAL NA HISTÓRIA?

ficor dentero do oleo

4 - DESENHE O PERSONAGEM PRINCIPAL DA HISTÓRIA.
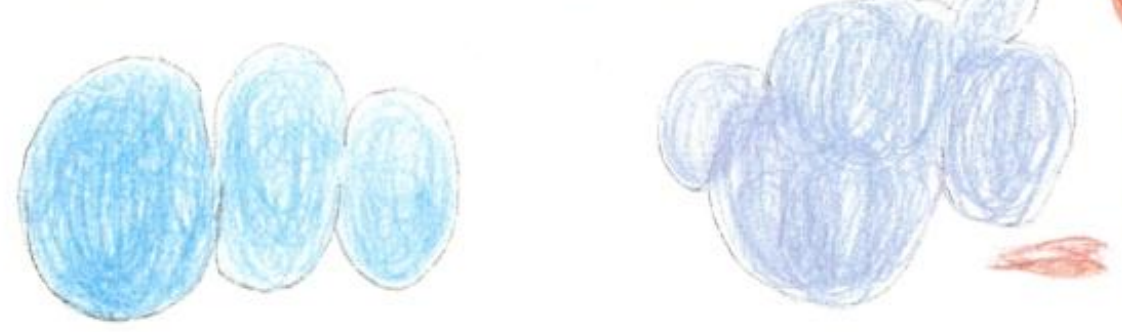
45
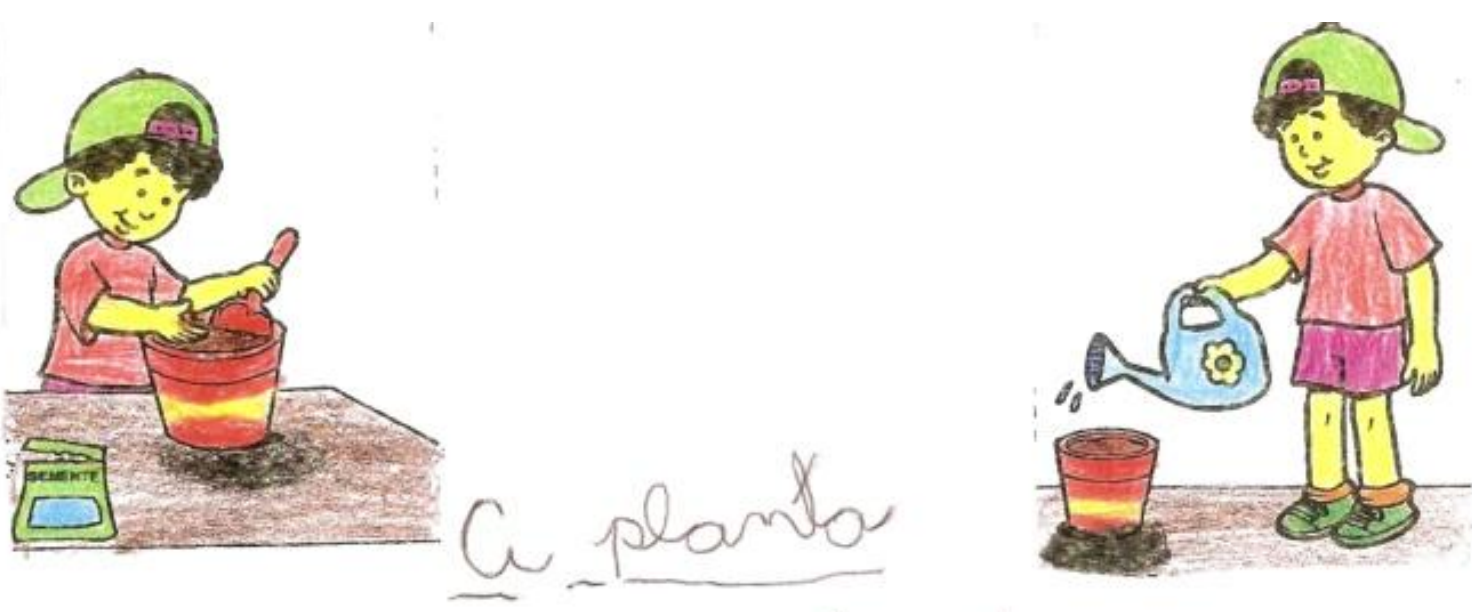

- menino plantall a semente em un vaso com terra.

$(O$ menino todos os idias regarea a sememtinh l ficaba olbandolla virar win semenfinha fim
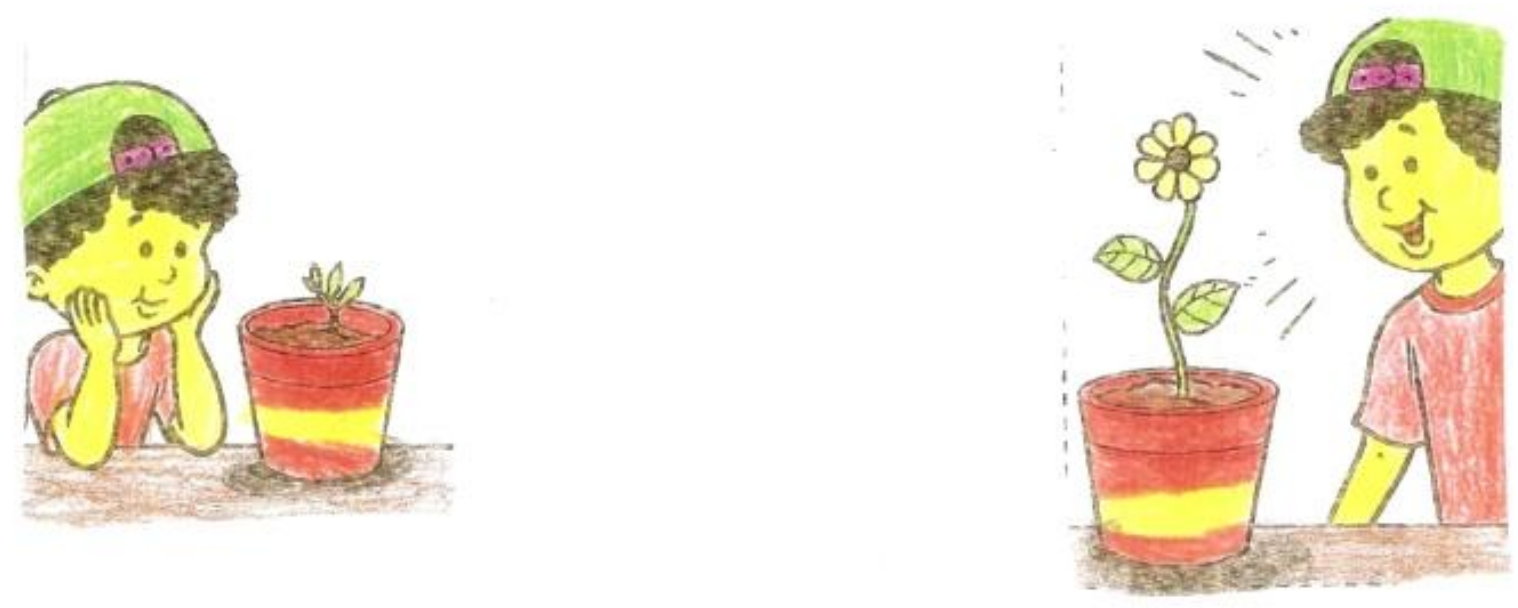


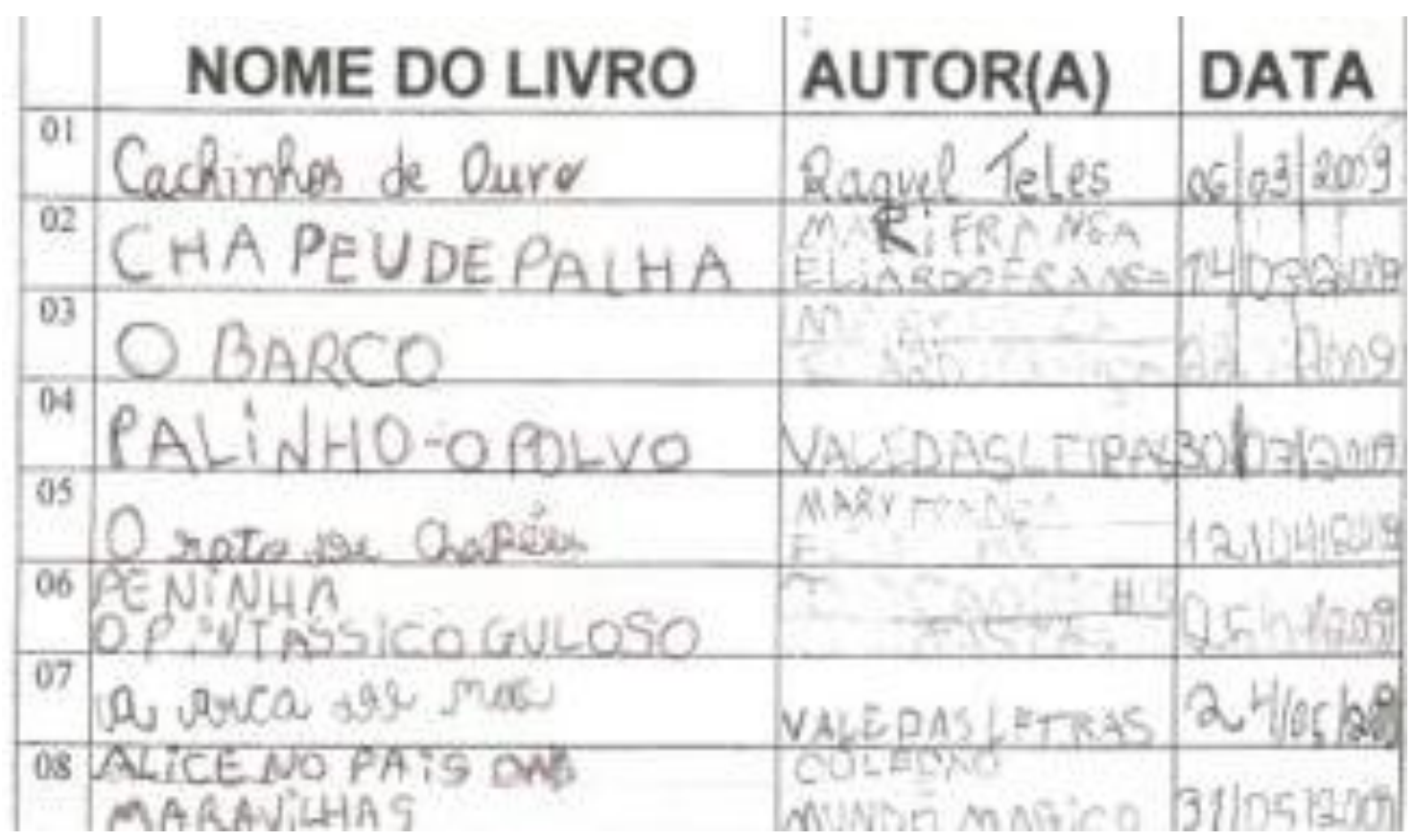

